\title{
U.S. STOCK MARKET CRASHES AND THEIR AFTERMATH: IMPLICATIONS FOR MONETARY POLICY
}

\author{
Frederic S. Mishkin \\ Eugene N. White \\ Working Paper 8992 \\ http://www.nber.org/papers/w8992
NATIONAL BUREAU OF ECONOMIC RESEARCH
1050 Massachusetts Avenue
Cambridge, MA 02138
June 2002

This paper is based on a paper delivered to the Asset Price Bubbles Conference, sponsored by the Federal Reserve Bank of Chicago and The World Bank on April 23, 2002. We thank Michael Bordo, Hugh Rockoff and participants in the Columbia macro lunch for their helpful comments. The views expressed herein are those of the authors and not necessarily those of the National Bureau of Economic Research, Columbia University or Rutgers University.

(C) 2002 by Frederic S. Mishkin and Eugene N. White. All rights reserved. Short sections of text, not to exceed two paragraphs, may be quoted without explicit permission provided that full credit, including $(\mathcal{C}$ notice, is given to the source. 
U.S. Stock Market Crashes and Their Aftermath: Implications for Monetary Policy Frederic S. Mishkin and Eugene N. White

NBER Working Paper No. 8992

June 2002

JEL No. E58, E44, N22

\section{ABSTRACT}

This paper examines fifteen historical episodes of stock market crashes and their aftermath in the United States over the last one hundred years. Our basic conclusion from studying these episodes is that financial instability is the key problem facing monetary policy makers and not stock market crashes, even if they reflect the possible bursting of a bubble. With a focus on financial stability rather than the stock market, the response of central banks to stock market fluctuations is more likely to be optimal and maintain support for the independence of the central bank.

Frederic S. Mishkin

Graduate School of Business

Uris Hall 619

Columbia University

New York, NY 10027

and NBER

fsm3@columbia.edu
Eugene N. White

Department of Economics

Rutgers University

New Brunswick, NJ 08901

and NBER

white@economics.rutgers.edu 


\section{INTRODUCTION}

In recent years, there has been increased concern about asset price bubbles and what monetary policymakers should do about them. For example, the stock market collapse in Japan in the early 1990s, which is seen as the bursting of a bubble, has been followed by a decade of stagnation. Concerns about a stock market bubble in the United States were expressed by Alan Greenspan in his December 5, 1996 speech when he raised the possibility that the stock market was displaying "irrational exuberance".

To understand what the implications of stock market bubbles might be for monetary policy we pursue a historical approach. Because it is far from obvious when the stock market is undergoing a bubble, we look at historical episodes in the United States over the last one hundred years of major stock market crashes. Although we cannot be sure that all these crashes were bubbles, a bursting of a bubble surely results in a stock market crash and so analyzing the aftermath of stock market crashes can provide some clues as to the impact of a bursting bubble and what policymakers should do about it.

The paper is organized as follows. First we describe the data and the procedures we used to identify the stock market crashes in the United States over the last one hundred years. Then we pursue a narrative approach to discuss what happened in the aftermath of these crashes, and then end by drawing out the implications for monetary policy.

\section{THE DATA AND CHOOSING EPISODES OF STOCK MARKET CRASHES}

Whether stock market crashes may be attributed to expectations of an economic decline or a loss of "irrational exuberance", they are believed to have an independent effect on economic 
activity. The shock is transmitted via the effect that a large loss in wealth has on consumer spending and through effects on the cost of capital on investment, both of which are standard channels in the monetary transmission mechanism. ${ }^{1}$ Because stock price movements have an important impact on economic activity through these standard transmission mechanisms, central banks that are trying to conduct monetary policy in an optimal manner will necessarily react to them. However, the question arises as to whether the monetary authorities should react to stock market fluctuations over and above that indicated by their effect on the economy through the standard transmission mechanisms. For example, Cecchetti, Genburg, Lipsky and Wadhwani (2000) argue that central banks should at times react to stock prices in order to stop bubbles from getting out of hand. ${ }^{2}$ Alternatively, the monetary authorities might want to try to prop up the stock market after a crash, by pursuing expansionary policy greater than that which would be indicated by simply looking at the standard transmission mechanisms of monetary policy. Such strategies might be appropriate if stock market crashes produce additional stress on the economy by creating financial instability.

As pointed out in Mishkin (1997), financial instability may arise when shocks to the financial system increase information asymmetries so that it can no longer do its job of channeling funds to those with productive investment opportunities. Whether this happens depends on the initial condition of financial and non-financial firms' balance sheets. If balance sheets are initially strong, then a stock market crash might not increase asymmetric information substantially because the shock from the crash will still leave them in a healthy condition. On the other hand, if balancesheets start out in a weakened condition, then a stock market crash will leave balance-sheets in a precarious state, which can lead to financial instability and a sharp decline in economic activity.

\footnotetext{
${ }^{1}$ See Mishkin (1995).
} 
Stock market crashes may heighten informational problems arising from adverse selection and moral hazard. A stock market crash when balance sheets are initially weak increases adverse selection in credit markets because net worth of firms falls to very low levels (or may even be negative) and no longer functions as good collateral for loans. As pointed out in Calomiris and Hubbard (1990) and Greenwald and Stiglitz (1988), this worsens the adverse selection problem because the potential loss from loan defaults are higher, leaving the lender uncertain about whether a borrower is a poor credit risk. Uncertainty, which often accompanies a stock market crash in the form of increased volatility of asset prices, will also make it more difficult for lenders to screen out good from bad borrowers. The result of the increase in adverse selection will be that lenders pull out of the credit market, and a sharp contraction in lending and economic activity will then result.

A stock market crash which leaves firms' balance sheets in a weakened state also increases the moral hazard problem. As demonstrated by Bernanke and Gertler (1989), when a stock market crash leaves firms with low net worth, they then have little at stake and so are likely to take risks at the lender's expense. The resulting increase in moral hazard thus also produces a contraction in lending and economic activity. Furthermore, if there is no deposit insurance, stock market crashes might also reduce financial intermediation by promoting a bank panic in which depositors, fearing for the safety of their deposits withdraw them from the banking system, causing a contraction of bank loans. Given that banks perform a special role in the financial system (Battacharya and Thakor, 1993) because of their capacity to more closely monitor borrowers and reduce problems generated by information asymmetries, shocks that force them to curtail lending will also promote financial instability and a contraction.

The stress on the financial system from a stock market crash should become visible in

\footnotetext{
${ }^{2}$ For an opposing view, see Bernanke and Gertler (1999).
} 
interest rate risk premiums. The mechanisms above suggest that an important manifestation of financial instability would be a large rise in interest rates for borrowers for whom there is substantial difficulty in obtaining reliable information about their characteristics. There would be a much smaller effect on interest rates to borrowers for whom information about their characteristics is easily obtainable. Low quality borrowers are more likely to be those firms for which information about their characteristics is difficult to obtain, while high quality borrowers are more likely to be ones for which the asymmetric information problem is least severe. Consequently, a stock market crash which produces financial instability should lead to a rise in interest rate spreads for low versus high quality bonds.

To examine whether stock market crashes are associated with financial instability, we look at all stock market crashes in the twentieth century, examining what happens to interest-rate spreads and real economic activity. On the face of it, defining a stock market crash or collapse is simple. When you see it, you know it. However, attempting a more precise definition and measurement over the course of a century is more difficult. The choice of stock market index, the size of the collapse and the time frame of the decline are key factors. To select the biggest stock market declines in this paper we have examined the behavior of three well known stock indexes. The first is the Dow Jones Industrials, which represents a select group of large, leading companies and is an equally weighted index. Initially, there were 20 stocks in the index, with the number increasing to 30 on October 1, 1928 (Pierce, 1991). ${ }^{3}$ The second index is the Standard and Poor's 500 and its predecessor the Cowles Index. This value-weighted index offers broad coverage of

\footnotetext{
${ }^{3}$ The daily Dow Jones index was obtained from www.economagic.com. The end-of-month figures for the index were provided by NBER's Macro History database series 11009a and 11009b (www.nber.org) for 1900 to 1968 and www.economagic.com for 1968 to 2001.
} 
the stock market. ${ }^{4}$ Lastly, representing smaller and lately high tech firms, the NASDAQ composite index, for 1971-2001, was examined. ${ }^{5}$. Crashes are discussed in nominal terms, except when there were significant differences in real and nominal movements. ${ }^{6}$

As October 1929 and October 1987 are universally agreed to be stock market crashes, the procedure to identify stock market crashes used them as benchmarks. On October 28 and 29, 1929, the Dow Jones declined 12.8 and 11.7 percent; and on October 19, 1987, the Dow Jones fell 22.6 percent. As both fell slightly over 20 percent, a 20 percent drop in the market is used to define a stock market crash. The fall in the market, the depth is, however, only one characteristic of a crash. Speed is another feature. Therefore, we look at declines over windows of one day, five days, one month, three months, and one year. For the effects that a crash can have on the market, the duration of the crash is also important. To cast a fine net to capture the features of speed and depth, we sorted the percentage changes for each window and looked at the fifty largest declines.

The Dow Jones is only index available on a daily and weekly basis for the whole of the twentieth century. Only 1929 and 1987 had one or two day declines of 20 percent or more, and their weekly declines were even greater. No additional 20 percent crashes were evident for a span of five days, although the five days ending July 22, 1933, the market fell 18.6 percent. The one month window finds crashes in the Dow for October and November 1929, October 1987, April

\footnotetext{
${ }^{4}$ The end-of-month Cowles index for 1900 to 1945 was obtained from the NBER's Macro History database series 11025, and the end-of-month S\&P 500 for 1946-2001 was found at the Freelunch website, www.economy.com. ${ }_{6}^{5}$ The end-of-month NASDAQ composite index was found at www.economagic.com for 1971-2001.

Although most observers consider only the nominal value of stocks when they describe a crash, over long periods of time, the real value of securities is a concern. To obtain the real value of the indexes, the consumer price index (1982-1984=100) was employed. The monthly CPI from 1910 to 2001 was obtained from the NBER's Macro History data base, series 04072 and 04028 . Lacking a good measure for the first decade of the twentieth century the wholesale price index (series 04048b) was spliced to the CPI, though it should be cautioned that this index is more volatile than the CPI.
} 
1932, and December 1931, while the S\&P500 picks out only November 1929 and April 1932. Thus, at one month there is one additional crash---which dominates the procedure---the relentless fall of the market from 1930 to 1932 . At one month, the only decline near the 20 percent cutoff is April 2000 at 19.6 percent.

At three months, the Dow additionally identifies, several more months in the 1930-1932 slide, November and December 1987, October and November 1907, October, November and December 1937, and June 1962. Similarly, the S\&P500 finds crashes in 1929, 1930-1933, 1937, 1962, 1974, and 1987, with June 1940 narrowly missing at 19.2 percent. For the NASDAQ, there are crashes in a three-month window in 1974, 1987, 1990, 2000, 2001

For the Dow Jones, declines in the 12 month window in excess of 20 percent, pick out 1900, 1903, 1904, 1907, 1908, 1914, 1915, 1917, 1920, 1921, 1930-1933, 1937, 1938, 1970, 1974, and 1988. Using the S\&P500 and a 12 month window there are crashes, ending in months in 1903, 1907, 1908, 1917, 1918, 1920, 1930-1933, 1937, 1938, 1941, 1947, 1970, 1974, and 1975. Looking at the NASDAQ for one year crashes, we pick out the same years as using a three month window, plus 1973, 1975, 1982, 1983, and 1984.

According to our procedure we find 15 major stock market crashes in the twentieth century, which are presented in Figures 1 to 13 . These show monthly stock market indexes centering on the crash with windows of three years before and after the crash. The stock market index is set at 100 in the month prior to the month conventionally identified as the crash, even though the downturn may have begun well before this date. The Dow Jones index is used for 1903 to 1940 . In 1946, we shift to the S\&P500 when it is first reported.

In the pre-Federal Reserve era, there were two crashes, 1903 and 1907. The crash of 1903 
began when market started to fall from its peak in February 1903 and hit bottom in November 1903, recovering by November 1904. Shown in Figure 1, the Dow Jones dropped 34.1 percent peak to trough. In Figure 2, the 1907 crash began when the market descended from its peak in December 1906. Hitting bottom in November 1907, the Dow Jones fell 40.9 percent.

During World War I and its aftermath, there were three distinct crashes in the market. However, we exclude the 1914-1915 crash because although there is a drop, stock markets were closed from July 31 to to December, 12, 1914, leaving little data for analysis. The stock market peaked in November 1916 and hit bottom in December 1917, collapsing 34.9 percent in the crash of 1917 depicted in Figure 3. Also shown in Figure 3 is the crash of 1920. The market recovered from its previous low in July 1919 and then peaked in October 1919. A slide began that finally found its trough in August 1921, for a total drop in the Dow Jones of 41.2 percent. Recovery in prices was not achieved until December 1924.

The crashes of 1929 and 1930-1933 are presented in Figure 4. The stock market boom of the 1920s peaked in September 1929, then rapidly fell 37 percent by the end of November 1929. After the crash of 1929, there were several months of recovery, although stock prices did not return to their September 1929 levels before new shocks forced stock prices to drop again. The recovery partial ended in April 1930, and a long bumpy slide downwards began. Measured by either the Dow Jones or the Cowles, the market reached its nadir in May 1932 when it slowly and unevenly began to rise. The drop from peak to tough was 81.8 percent. We call this the crash of 1930-1933, even though the Dow Jones did not reach the April 1930 level again until 1952. Although the market had not recovered, there was another crash in the late 1930s. The market had a local peak in August 1937, before it plunged 39.3 percent to a low point in April 1938. 
This crash of 1937 is shown in Figure 5.

At the outset of World War II, a collapse of stock prices began, seen in Figure 6. Peaking in April 1940, a 20.5 percent drop brought them to a low in June 1940. Figure 7 records the crash of 1946, where after reaching a peak in May 1946, prices fell a total of 25.3 percent through to May 1947.

Not until the 1962 was there another crash. After rising through December 1961, the S\&P500 dropped and the collapsed to a low in June 1962. Figure 8 shows this 22.5 percent fall. The market again peaked in November 1968, then moved downwards to a trough in June 1970, presenting a 30.6 percent decline, seen in Figure 9. Viewed in Figure 10, an even larger crash began from a high in January 1973, when prices fell 45.7 percent through to December 1974.

The second "great" crash of October 1987 is shown in Figure 11. Reaching a high in August 1987, the market plummeted 26.8 percent by December 1987. After this epic crash, there are several 3 month and one year movements in 1982 and 1984 of over 20 percent decline in the NASDAQ, but these are not counted as a bona fide crash as they mirror more extreme volatility, with relatively quick corrections. Also, there is no folklore on "the Street" about these movements constituting a crash. Figure 12, displays the collapse of 1990. According to the Dow Jones and the S\&P500, this episode should not qualify as the June to October 1990 decline amounted only to 14.7 percent. However, it is the NASDAQ which pushes the downturn in 1990 into the category of a crash. From October 1989 to October 1990, there was a 28.0 percent tumble in the market. Lastly, the most recent retreat of the market is shown in Figure 13. Reaching a peak in August 2000, the market had fallen 22.9 percent by December 2001, according to the S\&P500. The collapse is much more severe when measured by the NASDAQ, 
which fell 50.7 percent from its July 2000 peak to December 2001.

To examine the effects of stock market crashes on credit markets, we needed a measure of real activity for the economy. For this purpose, we selected the quarterly series for real GDP produced by Nathan Balke and Robert Gordon (1986) and measured in 1972 dollars. No interest rate series covered the whole of the century that could have produced an interest rate premium. The interest rate spread for the 1920s onward is the difference between Moody's Aaa corporate bond rate and Moody's Baa corporate bond rate. ${ }^{7}$ However before 1919, an alternative measure is required. The spread used here was constructed by Mishkin (1991) using Macaulay's (1938) data by subtracting the average yield on the best one-fourth of the bonds from the average yield on the worst one-fourth of the bonds. As discussed in Mishkin (1991), this spread series has some disadvantages over the Baa-Aaa spread. First by the beginning of the nineteenth century, even the lowest quality railroad bonds are of relatively high quality, thus making this spread substantially smaller than the Baa-Aaa spread. Thus it might not display a sufficient difference in the quality of bonds to pick up the changes in the interest rates for low- and high-quality borrowers. Nevertheless, the correlation of this spread variable and the Baa-Aaa spread is quite high - 0.88 -for the period when data for both are available, 1919-35. It is important to note that that the level of the two spreads is quite different and so the scale for the spreads in the first three figures is not comparable to those for the later figures.

Clearly, one single interest rate spread for each stock market crash episode does not capture the full effect of increased risk in credit markets. Shocks that raise the Aaa-Baa spread will have even larger impacts on higher risk securities. Unfortunately, long term series for these are not available, nor is data on bank loan rates and how credit might be rationed. However, where some

\footnotetext{
${ }^{7}$ These series were obtained from the FRED data base maintained by the Federal Reserve Bank of St.Louis. See 
data is available the series will be supplemented by a description of additional data in the narrative.

\section{STOCK MARKET CRASHES AND THEIR AFTERMATH}

The effects of a stock market crash on the pricing and availability of credit is not easily modeled econometrically. Over the course of a century, there are few series available over long spans of time. Even when they are, their interpretation may change dramatically. Furthermore, some key factors, like the strength of the financial system, are difficult to measure. Thus, in this paper we follow a narrative approach to pull together the complex stories of the consequences of stock market crashes on the credit markets.

Whether a stock market crash will have a distinct and severe effect on the terms that credit are offered to higher risk borrowers, thereby transmitting an independent shock to the economy, depends critically on two factors. First, the initial condition of the financial system is important. If the financial system is weak, being highly leveraged or having experienced cumulative shocks, it is more likely that a crash will induce lenders to raise rates to higher risk borrowers relative to low risk ones and produce financial instability. Secondly, given that a shock transmitted from the stock market crash promotes financial instability, how the monetary authorities react is critical. They can ignore the shock, in which case interest rate spreads will rise sharply, or they can inject liquidity into the system and dampen its effects. Lastly, it should be added that the more rapid and violent the crash, the more likely it will be a surprise; and intermediaries will have less time to make adjustments other than altering the terms of credit. 
The first crash of the twentieth century occurred in 1903, an event often referred to as the "rich man's panic" and identified as occurring in October 1903. However, as can be seen in Figure 1, the decline in the market began much earlier. The Dow Jones fell by 7.5 percent in July 1903 , and by almost the same amount, 8.2 percent, in October. By the end of this month, the index was down 16 percent over the year. By the Cowles index, the biggest monthly decline was in August 1903, 12.9 percent, and the yearly decline to September 1903 was a cumulative 26.8 percent. Whether the stock market anticipated or followed the business cycle is unclear. The NBER dates the peak of the cycle in the last quarter of 1902, while the real GDP data, shown in Figure 1, indicates that the decline began a year later. This difference is the result of the fragile nature of economic data in the early twentieth century. In any event the economic contraction was relatively mild, and the banking system had experienced no prior stress.

The stock market collapse began when banks called in the loans of underwriting syndicates, which had sponsored new issues in the previous two years. The syndicates responded by selling the unsold underwritten securities plus older higher grade stocks and bonds. This liquidation in the last quarter of 1903 helped to drive down the market. According to Friedman and Schwartz (1963) railroads found it difficult to borrow, and other companies and financial houses failed. The effect of the collapse on spreads was relatively mild. Using Mishkin's (1991) spread in Figure 1, there is no significant movement in the spread, even as interest rates rose. However, looking at the difference between high grade industrial bonds and high grade railroad bonds, where the former would have been considered riskier in this period, there is a rise in the spread of 25 basis points. ${ }^{8}$ Part of this mild effect of the stock market may be attributed to the actions of Secretary of the

${ }^{8}$ Both series are from Standard \& Poor's. The high grade railroad bonds and the high grade industrial bonds are 
Treasury Leslie M. Shaw. In the absence of a central bank, he anticipated the November payment of interest on outstanding bonds, bought bonds for the sinking fund at high premiums and increased government deposits at national banks, adding significantly to funds available to the money market (Friedman and Schwartz, 1963). Although the stock market crash of 1903 represented a large fall in stock prices, the initial soundness of the financial system and the monetary response of the Treasury led to a result in which there was little evidence of financial instability.

1907

The crash of 1907 is the first stock market collapse of the twentieth century that had a discernable effect on the credit markets. After a sustained boom in the stock market from 1904 through 1906, the market began to collapse in early 1907, as seen in Figure 2. As measured by the Dow Jones, the market sustained losses of 9.7 percent in March 1907, 8.2 percent in August 1907, and then 11.3 and 10.9 percent in October and November of that year. ${ }^{9} \quad$ Real GDP continued to grow through the end of the second quarter of 1907, before falling 1 percent by the third quarter and then a shocking 5.5 percent in the last quarter. The NBER dates the peak of the business cycle as May 1907, with a long slide to the trough in June 1908.

The rapidly declining stock market, well in advance of the economy may have been an important factor stressing the financial system, and spreads began moving upwards. The financial system appears to have been much more susceptible than in 1903, with banks becoming involved in more risky ventures and a serious rivalry emerging between banks and their newest competitors, trust companies. One speculative venture, the manipulation of shares of copper companies in the

available on the Macro History data set in the NBER's web site (WWW . nber . org) as series, 13024 and 13026. ${ }^{9}$ The Cowles index showed similar movements with declines of 15.2, 18.6 and 17.0 percent in March, October, and November 1907. 
midst of a boom in the price of copper, failed. Eight banks associated with this activity were forced to seek assistance from the New York Clearing House on October 14, which in the years before the establishment of the Federal Reserve provided some limited lender of last resort support. When the Knickerbocker Trust Company was discovered to have been involved in this venture, the Clearing House, composed of commercial banks, refused to come to its assistance. Knickerbocker was then forced to suspend payment on October 22, creating a banking panic first in New York and then throughout the country. A nationwide suspension of specie payments to depositors quelled the panic and payments were not resumed until January 1908 (Sprague, 1910, Friedman and Schwartz, 1963, Mishkin, 1991, Wicker, 2000).

The clearinghouses in New York and other cities began to issue clearinghouse loan certificates, a partial substitute for high power money, in late October 1907. However these institutions were not full-fledged lenders of last resort; their inability to halt the crisis eventually led to the creation of the Federal Reserve. The delay in the action of the clearinghouse was not compensated by the actions of Secretary of the Treasury George Cortelyou. As in 1903, the Tresury tried to increase funds to the money market, depositing government funds in banks and exempting them from the legal reserves against these deposits while stimulating the importation of gold. But these actions were limited and late (Wicker, 2000).

Friedman and Schwartz (1963) identify a $2 \frac{1}{2}$ percent drop in the money stock from May to September 1907 as putting downward pressure on the economy. They point to the fall in the money stock following the panic as a key factor turning a mild recession into a severe one that lasted until June 1908. However, while the banking panic clearly contributed to the economic decline, the spreads had been widening well before October 1907. The first phase of the stock market decline 
and rise in the risk premium was not accompanied by a falling money stock. It appears that the declining value of firms on the stock markets independently increased the adverse selection and agency problems for borrowers, effectively lowering their net worth. Numerous examples from the financial press indicate that these became severe problems early in the crisis. In March 1907, the price of Union Pacific shares, which were widely used to collateralize finance bills, fell by 50 points in less than two weeks. Then in June, New York City's new bond offering of \$29 million failed with only $\$ 2$ million being purchased (Sprague, 1910). In general, as seen in Figure 2, most of the increase in the spread occurred in advance of the banking panic, although there was a sharp increase in October and November. Once the stock market began to rebound, the risk premium started to decline, in advance of the economic recovery.

Given the exposure of the banking system, and the late and limited response of the Treasury, the crash of 1907 thus might have been an important factor that increased risk premiums in the credit markets, thereby contributing to a severe recession.

\section{7}

World War I and its aftermath produced huge fluctuations in the stock market. At the outset of the war, the market began a rapid descent. This drop was terminated when all markets were closed from the beginning of August to December 12, 1914 in fear of a banking and financial crisis.

Figure 3 shows the crash in the second half of 1917. In nominal and real terms (taking into account the high wartime inflation), these were huge declines. In the twelve months ending November 1917, the Dow Jones fell 33.8 percent in nominal terms and 44.4 percent in real terms.

The crash of the market in late 1917 is stunning. It is notable, especially as the economy 
was booming. Real GDP in Figure 3 is clearly on the rise and the peak of the NBER business cycle was only reached in August 1918. The rising spread as the collapse of the market proceeded is thus noteworthy. Other spreads also increased in this downturn including the Junk-AAA spread which increased over 1 percent (Basile, 1989). The market decline, although large in magnitude, has been virtually ignored by historians. However, it would appear that the fall in share prices may be attributed in part to generally rising interest rates and controls on new capital issues. Furthermore, there were strong efforts to divert financial resources to the purchase of government bonds to the finance the war (Friedman and Schwartz, 1963).

1920

The post-World War I fall in the market, although spread over a long period, was quite large, as viewed in Figure 3. For the twelve months ending December 1920, the Dow Jones index fell 31.8 and 31.5 percent in nominal and real terms respectively. The Cowles Index mirrors the Dow Jones for 1917, but for the 1920 collapse this index is not in the top 50 crashes in nominal or real terms.

In the quickly declining market of late 1920, the economy was entering a very steep recession. The peak of the business cycle, according to the NBER dating, was reached in January 1920, with the economy spiraling downwards until July 1921. As the world economy moved into recession, the decline in the U.S. was driven onwards by the Federal Reserve's efforts to halt inflation, raising discount rates sharply from January to June 1920 (Romer and Romer, 1989). Although gold inflows, offset some of its efforts, the Fed managed an 11 percent decline in total high-powered money from September 1920 to the trough of the business cycle in July 1921. This 
contraction did not produce a banking panic, but it did induce a rise in bank failures from 63 in 1919 to 506 in 1921 . Declining asset values rather than liquidity problems were at the root of most of these failures. The spread in Figure 3 rose very quickly as the market dropped but then stabilized, while the Junk-AAA (Basile, 1989) spread remained at the high level it had reached following the 1917 crash. The Baa-Aaa spread (which is available from 1919 on) also rose by 95 basis points from a low of 1.57 in October 1919 to a high of 2.52 in August 1921. With the recover of the market and the economy, the spreads again fell to lower levels. The weakened condition of the banking system, the tight monetary policy of the Fed, all contributed to the substantial rise in the interest rate spread.

\section{9 and 1930-33}

Although we will treat them separately, the two "great" crashes of 1929 and 1987 are an important pairing. The pattern of the crashes---with spectacularly rapid declines in stock prices--were similar, as was the Federal Reserve's successful lender-of-last resort intervention to prevent effects of a crash from spilling over to the rest of the financial system (Mishkin, 1991). The monetary authorities response subsequently, however, offer an important contrast. After the crash of 1929, the Federal Reserve Board maintained its tight monetary policy, helping to push the economy into deeper recession. The stock market continued to collapse and distress to the financial system led to the highest ever risk premiums. Well aware of the aftermath of 1929, the Fed did not allow its concern for the market to distort its policy after October 1987. The economy continued to grow and the market recovered.

The stock market crash of October 1929 was one of the sharpest and most abrupt collapses. 
On two days October 28-29, the Dow Jones fell a total of 24 percent, down 19.6 percent for the month and down a further 22 percent in November. The Cowles index was down 10 percent in October and 25 percent in November 1929. Although Figure 4 shows that there was a brief recovery in the market in early 1930, it continued to bounce downwards almost continuously for the next two years, producing the greatest long-term market declines by any measure.

Given the magnitude of the shock, the behavior of the spread at first glance is puzzling, it rises as the market moved upwards in late 1928 and 1929 and then falls when the market plunges. Only when there is a slow sustained drop in share prices from mid-1930 onwards do spreads begin to soar off the chart. However, the behavior of the spreads in crux of the crisis can be largely explained by the actions of the Federal Reserve. Operating under a gold standard where gold flowed to France and there was a perceived need to aid the weak British pound, the Fed began a tight monetary policy in early 1928, with the discount rate rising from $3 \frac{1}{2}$ to 5 percent (Friedman and Schwartz, 1963; Hamilton, 1987). This policy was reinforced by the Federal Reserve's fears that excessive credit was fueling the boom in the stock market.

In February 1929, the Fed stepped up its policy of "direct pressure," instructing its member banks to limit "speculative loans," that is, loans to brokers. Finally, the Fed raised the discount rate in August 1929. However, higher rates and direct pressure did not suppress the demand for credit to buy stock, which was supplied by other intermediaries. Nevertheless, the market did extract a premium for brokers' loans, reflecting lenders' concerns that the rise in the market was not sustainable. Rates on brokers' loans had traditionally been similar to those on bankers' acceptances and commercial paper, relatively safe assets. But, in the boom, a premium arose for brokers' loans of 2 to 3 percent and the margin demanded climbed from 25 to 50 percent (White, 1990; Rappoport 
and White, 1993 and 1994). Some markets, like commercial paper, which declined by half in volume, and new foreign bonds, which almost disappeared, were squeezed by the flow of funds to brokers' loans. All risk premiums also moved upwards, including the Baa-Aaa depicted in Figure 4.

When the market collapsed in October 1929, banks and lenders of New York rushed to liquidate their call loans to brokers. In order to keep the call loan market from freezing up the Federal Reserve Bank of New York engaged in a classic lender-of-last-resort operation, very similar to one conducted in 1987. The New York Fed let it be known that member banks could borrow freely from the New York Fed in order to take over the brokers loans called by others. (Friedman and Schwartz, 1963). In addition, the New York Fed made open market purchases of \$160 million during this period, even though this amount was far in excess of what was auhorized by the Federal Reserve System's Open Market Investment Committee. As a result, New York City banks stepped into the breach and increased their loans. The crisis was contained and there were no panic increases in money market rates or threats to banks from defaults on brokers' loans. The premium on brokers' loans collapsed, as the market believed that there was no further danger. This decline in perceived risk was mirrored in fall in other risk premiums, including the Baa-Aaa spread.

Unfortunately, the Federal Reserve Board did not approve of the New York Fed's intervention. It censured the New York bank and in spite of the recession that had begun during the summer and was in full swing by the end of the year, the Board maintained its tight monetary policy. The tentative recovery in 1930, seen in the GDP movements in Figure 4 was aborted by this policy. The continued decline in the stock market from 1930 through early 1933 reflected the economy's policy-aggravated slide into depression. The collapsing economy placed enormous 
stress on the banking system. The banking crises of 1930, 1931 and 1933 undermined intermediation (Friedman and Schwartz, 1963; and Bernanke, 1983, Mishkin, 1991), contributing further to the decline of the economy. In these circumstances, risk premiums soared, as seen in Figure 4, as lenders fled from risky borrowers. ${ }^{10}$

The stock market collapse beginning in 1929 shows in high relief the importance of the two factors we have identified. In 1929, the banking system was relatively weak and the drop in the market was large and sudden. However, the effects were quickly contained by the response of the New York Fed. Yet, the further though less sudden decline in stocks and other asset values in the 1930s appears to have contributed to the rising risk premiums as the Fed stuck to its tight money policy.

\section{7}

The stress imposed on financial markets is perhaps most evident in 1937. In Figure 5, the stock market plunged as the economy moved into recession, while the interest rate spread increased much more sharply than in any other crash in the twentieth century. The decline in the market was steep but not greater than in other episodes. In three consecutive months, the market bounced downward, losing a total of 22.4 percent by December 1937 as measured by the Dow Jones and 22.8 percent by the Cowles index. By April 1938, both indexes had fallen by another 10 percent. The peak in the business cycle was reached in May 1937 and hit bottom in June 1938, over its course real GDP declined 10 percent. The leap in the risk premium shown in the spread variable in Figure 5, was in plain evidence elsewhere. The Junk-AAA premium increased from 4.1 percent to

\footnotetext{
10 Bank loans also began to carry large premiums relatively to bankers' acceptances, treasury securities or any other safe assets, rising from just over 0.5 percent in 1929 to 2 to 4 percent in the worst years of the depression. Banking and Monetary Statistics.
} 
10.4 percent from April 1937 to April 1938.

In early 1937, the Federal Reserve believed that it was time to tighten monetary policy. There had been steady economic expansion for two years, wholesale prices were up 50 percent and stock prices had doubled. Focusing erroneously on the nominal level of interest rates, which seemed extremely low, the Fed concluded that policy was easy. This conclusion was buttressed by the fact that commercial banks held very large excess reserves. Instead of using open market purchases or increases in the discount rate, the Fed decided that it should increase reserve requirements beginning in July 1936 (Friedman and Schwartz, 1963). In a series of actions in August 1936, and March and May 1937, the Fed doubled reserve requirements, jacked up margin requirements for stock purchases, and cut slightly the discount rate. Banks responded by cutting lending to restore their excess reserves, contributing to the sharp contraction.

The decline in the stock market reflects the seriousness of the economic downturn. However, the decline in asset values may have been a key part in the increase in the interest rate spread. The banking system had taken a pounding during the banking crises of 1930, 1931, and 1933. In June 1929, there had been 24,504 commercial banks with $\$ 49$ billion of deposits. After the banking panics, and the March 1933 bank holiday, the number of banks had been winnowed to 14,440 with $\$ 33$ billion of deposits by December 1933 . The rush for liquidity by the banking public had been accompanied by an effort by the banks to increase their liquidity as well. They slashed their lending and vastly increased their holdings of cash and bonds. Savings banks, savings and loan associations, and insurance companies had suffered similar collapses and had moved to augment their liquidity (White, 2000).

In this dramatic rush to cut lending, banks and other intermediaries would have sought to 
avoid even more strenuously risky borrowers. Increased adverse selection and moral hazard problems would have then propelled risk premiums to higher levels, as is evident in Figure 5. The dramatic fall in asset values would have exacerbated this development. The lower value of firms would have made it increasing difficult for any one perceived to be risky to borrow either from an intermediary or on a financial market. The existing weakness of the banking system, tight monetary policy and the decline in the stock market and other asset values, were probably all factors in the rise of risk spreads, contributing further to the severity of the 1937-1938 recession.

\section{0}

In May and June 1940, with the defeat of France by the Germans and the Dunkirk evacuation, the Dow Jones and the Cowles index lost 20 percent of their value, as seen in Figure 6. While real GDP declined in first quarter of 1940, there was no recession and expansion continued until February 1945. Although small by comparison to jumps in the interest rate spread in 1937, there was a small but obvious increase during the collapse of the market. However, the spread still did not rise above levels reached in 1938 and 1939, and immediately fell to the pre-crash levels and then continued to decline. The economy and the financial system were in no immediate threat from the crash of the market. In September 1939 when war broke out in Europe, the Federal Reserve purchased $\$ 400$ million of government securities to offset the big fall in the price of U.S. government bonds. This action was regarded by the Federal Reserve Board, and probably the markets as well, as a break from past practice. The professed aim was to protect member bank portfolios and to ensure an "orderly" capital market for economic recovery (Friedman and Schwartz, 1963). This action and the steady growth of the money stock from rising gold flows may 
have limited the reaction of the credit markets to the stock market crash.

By 1940, the weaker financial institutions had been eliminated and the balance sheets of most banks and firms had been substantially strengthened. These improved initial conditions and the Fed's early policy intervention meant that the credit markets reacted very little to the stock market crash.

\section{6}

After several months of slow decline, there was an abrupt drop in the stock market in September 1946, of 12 percent measured by the Dow Jones and 14.7 percent by the S\&P500. This collapse is quite surprising as it came after the severe post-World War II recession. According to the NBER dating, the peak of the previous boom was in February 1945 and the bottom was hit in October 1945. The crash thus appears to be unrelated to the recovery of the economy. What is also striking is that there is almost no effect of the crash on the interest rate spread in Figure 7. The lack of response of the debt markets to the collapse in equity prices may be attributed to the continuance of the government's wartime policy of supporting the price of government bonds. The posted rate on Treasury bills was $3 / 8$ of 1 percent and $2 \frac{1}{2}$ percent on long term securities (Friedman and Schwartz, 1963). Any upward pull on these rates by higher rates elsewhere in the market was offset by open market operations by the Fed, which only decided to fight inflation in October 1947 (Romer and Romer, 1989).

The continued growth of the money stock and the bond price supports helped insulate the credit markets from the stock market crash. In addition, by the end of World War II, the financial system had been purged of almost any risk, except that derived from holding government bonds. 
Thus, not surprisingly, the collapse in stock prices in 1946 was not followed by significant rises in interest-rate spreads.

\section{2}

The stock market crash in 1962 occurred at a time when the economy was expanding. Real GDP, as seen in Figure 8, was rising and the expansion begun in February 1961 continued until December 1969. Beginning April 1962, the market had lost 20.6 percent of its value as measured by the Dow Jones by June and 20.9 percent by the S\&P500. Yet, this shock did little to drive the interest rate spread upward. In fact, it appears to have been remarkably steady. The banking system was very stable, there had been no significant loan losses or bank failures in decades. The Federal Reserve was concerned about maintaining orderly markets for treasury securities and kept interest rate movements modest. There was no monetary surprise from the Fed; contractionary actions were only undertaken in 1955 and 1966 (Romer and Romer, 1989). Thus, this shock from a stock market crash appears to have had little effect on interest rate risk premiums in credit markets.

\section{9-1970}

The sharp decline in the stock market in mid-1970 occurred at the time of a very mild recession. Although the economy had peaked in December 1969, the slowdown has been referred to as a "hiatus" rather than a recession (Gordon, 1980). However, the expansion was also quite sluggish. The market peaked in advance in November 1968, then began to drift downwards, declining abruptly in May 1970, as seen in Figure 9. Eventually, the market hit bottom in June 1970 , for a 30.6 percent drop. In this uncertain atmosphere when there was a decrease in the 
valuation of firms from a fall in net worth, adverse selection problems began to appear in credit markets and the spread began to widen.

By May 1970, Penn Central Railroad was on the verge of bankruptcy. The railroad asked for assistance first, from the Nixon administration and then the Federal Reserve. Both these requests were rebuffed and on June 21, 1970, Penn Central was forced to declare bankruptcy. As a major issuer of commercial paper, the Federal Reserve was concerned that this default would make it impossible for other corporations to roll over their commercial paper, producing further bankruptcies and perhaps a panic. To prevent this from happening, the Fed encouraged money center banks to continue lending, promising that the discount window would be available to them (Mishkin, 1991).

In spite of the Fed's actions in response to a potential problem in the commercial paper market, interest rate spreads widened. Not only did the commercial paper-Treasury bill spread rise (Mishkin, 1991), but so did the Baa-Aaa spread in Figure 9. The general rise in risk premiums indicates that problems of the commercial paper market had the potential for spreading to parts of the capital market. However, the increase in the spread variables from the Penn Central bankruptcy were not large by standards of other crises, and were likely to have been dampened by the prompt action of the Fed.

\section{3-1974}

One of the largest and longest stock market collapses, viewed in Figure 10, occurred in the early 1970s. Beginning with a monthly fall in the Dow Jones of 14 percent and the S\&P 500 of 7 percent in November 1973, the twelve month declines ending in October 1974 were 30.4 percent 
and 36.8 percent for the two indexes. At the same time as the market dropped, the economy moved into a recession that lasted until March 1975. The market crash was accompanied by a large increase in the interest rate spread in Figure 10. However, the increase occurred mostly after the stock market had hit its bottom. Unlike the earlier post-World War II decades, the financial markets and institutions were forced to cope with rising inflation and inflation uncertainty, following the OPEC oil price shock. The large decline in asset values also contributed to making low quality borrowers seem even worse risks. The existing condition of the banking system was not as favorable to the absorption of any shock. With a recession and inflation, bank earnings fell as borrowers failed to make payments and loan losses rose. Banks found an increased difficulty in funding, as market rates moved well above the Regulation Q ceilings that set rates for bank deposits. Banks found themselves troubled by real estate loans and loans made to non-oilproducing countries. In the previous two decades bank failures had been very rare and involved only small institutions. In October 1973, the first large bank failure since the depression occurred in San Diego, followed by failure of the nation's twentieth largest bank, Franklin National in October 1974. These failures highlighted the generally weakened state of the banking system (Sinkey, 1979; Spero, 1980; White, 1992).

The stock market crash in this environment aggravated the problems of agency costs, thereby reducing the willingness of lenders to provide low quality borrowers with credit and driving up the interest rate risk premiums. However, the fact that majority of the increase in the spread occurred well after the market had turned upward suggests that the other factors were important in producing financial instability. 
The October 1987 crash had the largest one-day decline in stock market values in U.S. history. On October 19, the Dow Jones fell 22.6 percent and for the month, the index was down 23.2 percent. As measured by the S\&P 500, the market fell 12.1 percent in October and 12.5 percent in November. Thus, the pattern of the rise and fall of the market for 1926-1929 in Figure 4 and 1984-1987 in Figure 11 look remarkably similar.

Unlike the 1920s, the Fed in the 1980s was no longer preoccupied by speculation, but after the 1970s it was concerned about inflation and tightened policy to prevent any acceleration. At the outset of the stock market boom, monetary aggregates had increased at a fairly rapid pace. But, in the first six months of 1987, their growth slowed considerably. Worried about rising foreign interest rates, a poor trade balance, and a weak dollar, interest rates in the U.S. rose in anticipation of action by the Fed, which increased the discount rate from 5.5 to 6 percent on September 4 (Mussa, 1994). These actions did not slow down the economy, and it continued to grow steadily as seen in the real GDP movement in Figure 11. The risk premium was steady, and the spread appears to have declined even when the market moved into the last phase of the boom in mid-1987.

The sharp decline on October 19 put the financial system under great stress because in order to keep the stock market and the related stock index futures market operating in an orderly fashion, brokers needed to extend huge amounts of credit on behalf of their customers for margin calls. The magnitude of the problem is illustrated by two brokerage firms, Kidder, Peabody and Goldman, Sachs, who by themselves had advanced $\$ 1.5$ billion in response to margin calls on their customers by noon of October 20. Clearly, brokerage firms as well as specialists were severely in need of additional funds to finance their activities. Despite the financial strength of these firms, there was 
so much uncertainty that banks were reluctant to lend to the securities industry at a time when it was most needed. The Federal Reserve thus began to fear that there would be a collapse of securities firms and a breakdown in the clearing and settlement systems. To prevent this from happening, Alan Greenspan, the Chairman of the Board of Governors of the Federal Reserve, announced before the market opened on October 20 the Federal Reserve System's "readiness to serve as a source of liquidity to support the economic and financial system." The Open Market Desk then supplied $\$ 17$ billion to the banking system, or more than 25 percent of bank reserves and 7 percent of the monetary base. In addition, commercial banks were told that they were expected to continue supplying other participants of the financial system with credit, including loans to brokerdealers to ensure that they could carry their inventories of securities. ${ }^{11}$ Spreads widened at the outset of the crisis, but then quickly decreased in response to the actions of the Fed. Although stock prices continued to oscillate violently for the remainder of 1987 , financial markets gradually calmed down. The Fed carefully withdrew most of the high-powered money that it had provided, ensuring that the Federal funds rate was stable at 6.75 percent or about 1 percent below the level before the crash.

Thus, cushioned by the Federal Reserve's action, which was reminiscent of the New York Fed's behavior in the October 1929 episode, the crash was not seen as a threat to the stability of the financial system or borrowers despite the large loss in equity values. Bank failures and loan losses were rising rapidly in the late 1980s, and yet the crash was prevented from damaging the susceptible financial system. There was almost no movement in the spread shown in Figure 10 from mid-1987 to mid-1988. ${ }^{12}$ The Fed's lender of last resort operation was again successful, but

\footnotetext{
${ }^{11}$ See Brimmer (1989) and Mishkin (1991) for a description of the Fed's lender-of-last resort role in this episode .

${ }^{12}$ However, as shown in Mishkin (1991), there was a sharp but brief increase in the junk bond-Treasury spread when the crash occurred. This suggests that there was the potential for the crash to lead to substantial financial instability, 
this time there was no overreaction to the boom in the market and monetary policy was focused on economic activity, not the stock market.

1990

In August 1990, a major stock market decline began with the Dow Jones falling 10 percent and the S\&P500 declining 8.1 percent. By October 1990, the market had fallen 15.9 percent and 14.7 percent by these measures. The decline in the market closely followed the movement of the economy into a recession, the peak of the expansion having been reached in July 1990. Yet, although the 1990-91 recession was a relatively mild one and the stock market decline was moderate, the interest-rate spread did rise substantially, as seen in Figure 12. A likely source of this widening of the spread was the very weak initial condition of depository institutions. The savings and loans already required a bailout from the government on the order of $\$ 150$ billion, while loan losses were increasing and commercial bank failures had risen to over 200 per year by the late 1980s. (White, 1992).

\section{0-2001}

Lastly, Figure 13 shows the most recent gyrations in the market. The sharp short slump beginning in July 1998, although it was not large enough to pass the simple test of a twenty percent drop, fell 12.7 percent in two months. GDP kept rising but the spread widened considerably. The current decline in the S\&P 500 began in August 2000, falling 23 percent by December 2001. The collapse mirrored the slowing economy that moved into a recession in March 2001. However, it important to note that the collapse in stock prices has not been evenly felt across the market. 
Between August 2000 and December 2001, the Dow Jones dropped approximately 11 percent, the S\&P500 fell 23 percent and the NASDAQ nearly 49 percent. The higher tech, higher risk stocks took a beating. Yet, this did not immediately translate into a higher risk premium for these borrowers even in the aftermath of the September 11 terrorist attacks and the recession, which had started six months earlier. One explanation for this stability is that the financial system has been stronger than at any time since the 1960s. The weak banks have been culled out by failure and merger, and new regulations and a long period of growth made intermediaries stronger and less susceptible to a sudden decline in asset values. Thus, there was no reason for a squeeze on the less creditworthy customers, despite the decline in the stock market. However, there was a sharp increase in the spread in December 2001 continuing into 2002. This development did not reflect any change in the stock market but rather the Enron scandal. The revelations of fraud and misleading accounting indicated that the quality of information about corporations was weaker than the markets had supposed. Given the revelation of greater information asymmetries, it is not surprising that risk premiums rose.

\section{IMPLICATIONS FOR MONETARY POLICY}

The description of the fifteen episodes of twentieth century stock market crashes suggests that we can place them into four categories.

1. Episodes in which the crashes did not appear to put stress on the financial system because interest-rate spreads did not widen appreciably. These include the crashes of 1903, 1940, 1946, 1962 and 2000.

2. Episodes in which the crashes were extremely sharp and which put stress on the 
financial system, but where there was little widening of spreads subsequently because of intervention by the Federal Reserve to keep the financial system functioning in the wake of these crashes. These include the crashes of 1929 and 1987.

3. Episodes in which the crashes were associated with large increases in spreads suggesting severe financial distress. These include the crashes of 1907, 1930-33, 1937, 1973-74.

4. Episodes in which the crashes were associated with increases in spreads that were not as large as in the third category, suggesting some financial distress. These include the crashes of 1917, 1920, 1969-70 and 1990.

Obviously, deciding which crashes go into categories 3 and 4 is somewhat arbitrary. For example, the 1920 crash episode does have a substantially greater increase in the spread than 1917 using the Mishkin measure, but the increase for the Baa-Aaa spread (which was available from 1919 on) is similar to that in 1990 and is less than in the other category 3 episodes.

Looking at these four categories of crash episodes, what conclusions can we draw? First, is the fact that many stock market crashes (category 1) are not accompanied by increases in spreads suggests that stock market crashes by themselves do not necessarily produce financial instability. These episodes also are ones in which the balance sheets and the financial system are in good shape before the onset of the stock market crash. Furthermore, in these cases where financial instability does not appear, economic downturns tend to be fairly mild. Secondly, very sharp stock market crashes like those in 1929 and 1987 (category 2) do have the potential to disrupt financial markets. But actions by the central bank to prevent the crashes from seizing up markets--not to prop up stock 
prices---are able to prevent financial instability from spinning out of control. Thirdly, situations in which financial instability becomes severe, when spreads widen substantially (category 3) are associated with the worst economic downturns.

Because stock market crashes are often not followed by signs of financial instability, we must always be cautious about assigning causality from timing evidence. Certainly, one cannot make the case that stock market crashes are the main cause of financial instability. Indeed, in many episodes, a case can be made that the source of financial instability might have been caused by other factors, such as the collapse of the banking system or the severity of the economic contraction. Only in the case of the extremely sharp market crashes as in 1929 and 1987 do we have more direct evidence that some financial markets were unable to function as a result of the stock market crash. The theory of how stock market crashes can interfere with the efficient functioning of financial markets suggests that the impact of a stock market crash will be very different depending on the initial conditions of balance sheets in the economy. What then are the monetary policy implications of the analysis of the stock market crashes examined here? ${ }^{13}$ The first is that financial instability is the key problem facing the policymaker and not stock market crashes, even if they reflect the bursting of an asset price bubble. If the balance sheets of financial and nonfinancial institutions are initially strong, then a stock market crash (bursting of the bubble) is unlikely to lead to financial instability. In this case, the effect of a stock market crash on the economy will operate through the usual wealth and cost of capital channels, only requiring the monetary policymakers to respond to the standard effects of the stock market decline on aggregate demand. In this situation, optimal monetary policy, which focuses solely on minimizing a standard loss function, will not

\footnotetext{
${ }^{13}$ There are other implications for other types of policy besides monetary policy that are beyond the scope of this paper. For example, concerns about preventing financial instability lead to the need to focus on financial regulation and supervision, as is discussed in Mishkin (2000).
} 
respond to the stock market decline over and above its affects on inflation and output. Indeed, a regime of flexible inflation targeting, which is what all so-called inflation targeters actually pursue (see Bernake, Laubach, Mishkin and Posen, 1999), is consistent with this type of optimal monetary policy (Svensson, 1999). Also Bernanke and Gertler (1999) have shown that a regime of flexible inflation targeting is likely to make financial instability less likely and to be stabilizing in the presence of asset price bubbles.

However, central banks may see the need to directly respond to a stock market crash when the crash puts stress on the financial system in order to prevent financial instability. We have seen exactly this response of the Fed in the crashes of 1929 and 1987 when the Fed had direct evidence that financial markets were unable to function in the immediate aftermath of the crashes. What is important about both these two episodes is nature of the stress on financial markets. The source of stress had more to do with the speed of the stock market decline than the overall decline of the market over time, which has often been far larger with little impact on the financial system. Furthermore, in both episodes, the focus of the Federal Reserve was not to try to prop up stock prices but was rather to make sure that the financial markets, which were starting to seize up, would begin functioning normally again.

A focus on financial instability also implies that central banks will respond to disruptions in the financial markets even if the stock market is not a major concern. For example, as described in Maisel (1973), Brimmer (1989) and Mishkin (1991), the Fed responded aggressively to prevent a financial crisis after the Penn-Central bankruptcy in June 1970 without much concern for developments in the stock market even though it had an appreciable decline from its peak in late 1968. In the aftermath of the Penn-Central bankruptcy, the commercial paper market stopped 
functioning and the Fed stepped in with a lender-of-last-resort operation. The New York Fed got in touch with money center banks, encouraged them to lend to their customers who were unable to roll over their commercial paper, and indicated that the discount window would be made available to the banks so that they could make these loans. These banks then followed the Fed's suggestion and received $\$ 575$ million through the discount window for this purpose. In addition, the Fed, along with the FDIC and the Federal Home Loan Banks decided to suspend Regulation Q ceilings on deposits of $\$ 100,000$ or more in order to keep interest rates from rising, and the Fed supplied liquidity to the banks through open market operations.

Similarly, in the fall of 1998, the Fed supplied liquidity to the system and lowered the federal funds rate sharply by 75 basis points even when the market was at levels that were considered to be very high by Federal Reserve officials. The Fed's intervention stemmed from its concerns about the stress put on the financial system by the Russian crisis and the failure of Long Term Capital Management. A spectacular lender-of-last resort operation was also carried out in the aftermath of the destruction of the World Trade Center on Tuesday, September 11, 2001, the worst terrorist incident in U.S. history. Because of the disruption to the payments system, the liquidity needs of the financial system skyrocketed. To satisfy this need and so keep the financial system from seizing up, within a few hours of the incident, the Fed made a similar announcement to that made after the crash of 1987, stating, "The Federal Reserve System is open and operating. The discount window is available to meet liquidity needs." ${ }^{14}$ The Fed then proceeded to provide $\$ 45$ billion to banks through the discount window, a 200 fold increase over the previous week. As a result of this action, along with as much of $\$ 80$ billion of reserves injected into the banking system through open market operations, the financial system kept functioning. When the stock market

\footnotetext{
14 "Economic Front: How Policy Makers Regrouped to Defend the Financial System," Wall Street Journal, 
reopened on Monday, September 17, trading was orderly, although the Dow Jones average did decline percent.

These examples suggest the importance of having a central bank focus on the potential of financial instability per se. Too much of a focus on the stock market rather than on the potential for financial instability might lead central banks to fail to take appropriate actions as in 1970, 1998, and 2001, when the level of the stock market was not a primary concern.

Too great a focus on the stock market also presents other dangers for central banks. Too much attention on asset prices, in this case common stocks, can lead to the wrong policy responses. The optimal response to a change in asset prices very much depends on the source of the shock to these prices and the duration of the shock. An excellent example of this pitfall of too much focus on an asset price is the tightening of monetary policy in Chile and New Zealand in response to the downward pressure on the exchange rate of their currencies in the aftermath of the East Asian and Russian crises in 1997 and 1998 (see Mishkin and Schmidt-Hebbel, 2002). Given that the shock to the exchange rate was a negative terms of trade shock, it would have better been met by an easing of policy rather than a tightening. Indeed, the Reserve Bank of Australia responded in the opposite direction to the central banks of New Zealand and Chile, and eased monetary policy after the collapse of the Thai baht in July 1997 because it was focused on inflation control and not the exchange rate. The excellent performance of the Australian economy relative to New Zealand and Chile's during this period illustrates the benefit of focusing on the main objective of the central bank rather than on the asset price.

A second problem with the central bank focusing too much on stock prices is that it raises the possibility that the central bank will be made to look foolish. The linkage between monetary 
policy and stock prices, although an important part of the transmission mechanism, is still nevertheless, a weak one. Most fluctuations in stock prices occur for reasons unrelated to monetary policy, either reflecting real fundamentals or animal spirits. The loose link between monetary policy and stock prices therefore means that the ability of the central bank to control stock prices is very limited. Thus, if the central bank indicates that it wants stock prices to change in a particular direction, it is likely to find that stock prices may move in the opposite direction, thus making the central bank look inept. Recall that when Alan Greenspan made his speech in 1996 suggesting that the stock market might be exhibiting "irrational exuberance", the Dow Jones average was around 6500. This didn't stop the market from rising, with the Dow subsequently climbing to above 11000 .

An third problem with focusing on stock prices is that it may weaken support for a central bank because it looks like it is trying to control too many elements of the economy. Part of the recent successes of central banks throughout the world has been that they have narrowed their focus and have more actively communicated what they can and cannot do. Specifically, central banks have argued that they are less capable of managing short-run business cycle fluctuation and should therefore focus more on price stability as their primary goal. A key element of the success of the Bundesbank's monetary targeting regime was that it did not focus on short-run output fluctuations in setting its monetary policy instruments. ${ }^{15}$ This communication strategy for the Bundesbank has been very successful, as pointed out in Bernanke, Laubach, Mishkin and Posen (1999), has been adopted as a key element in inflation targeting, a monetary regime that has been gaining in popularity in recent years. By narrowing their focus, central banks in recent years have been able to increase public support for their independence. Extending their focus to asset

${ }^{15}$ See Bernanke, Laubach, Mishkin and Posen (1999). 
prices has the potential to weaken public support for central banks and may even cause the public to worry that the central bank is too powerful, having undue influence over all aspects of the economy.

A fourth problem with too much focus on the stock market is that it may create a form of moral hazard. Knowing that the central bank is likely to prop up the stock market if it crashes, the markets are then more likely to bid up stock prices. This might help facilitate excessive valuation of stocks and help encourage a stock market bubble that might crash later, something that the central bank would rather avoid.

This begs the question of whether monetary authorities should try to prick asset price bubbles, because subsequent collapses of these asset prices might be highly damaging to the economy, as they were in Japan in the 1990s. Cecchetti, Genburg, Lipsky and Wadhwani (2000), for example, argue that central banks should at times react to asset prices in order to stop bubbles from getting too far out of hand. However, there as serious flaws in their argument. First is that it is very hard for monetary authorities to determine if a bubble has actually developed. To assume that they can is to assume that the monetary authorities have better information and predictive ability than the private sector. If the central bank has no informational advantage, then if it knows that a bubble has developed that will eventually crash, then the market knows this too and then the bubble would unravel and thus would be unlikely to develop. Without an informational advantage, the central bank is as likely to mispredict the presence of a bubble as the private market and thus will frequently be mistaken, thus frequently pursuing the wrong monetary policy. Cecchetti, Genburg, Lipski and Wadhwani (1999) find favorable results in their simulations when the central bank conducts policy to prick asset price bubble because they 
assume that the central bank knows the bubble is in progress. This assumption is highly dubious because it is hard to believe that the central bank has this kind of informational advantage over private markets. Indeed, the view that government officials know better than the markets has been proved wrong over and over again.

\section{CONCLUSIONS}

This paper has examined fifteen episodes of stock market crashes in the United States in the twentieth century. The basic conclusion from studying these episodes is that the key problem facing monetary policymakers is not stock market crashes and the possible bursting of a bubble, but rather whether serious financial instability is present. Indeed, the situation depicted in Figure 13, which shows that the recent stock market crash has had little impact on interest-rate spreads, appears to be an episode in which the stock market crash that is not associated with financial instability. Thus, the current environment does not appear to be one that requires an unusual response to the stock market decline. With a focus on financial stability rather than the stock market, the response of central banks to stock market fluctuations is more likely to be optimal and maintain support for the independence of the central bank. 


\section{Bibliography}

Balke, Nathan, and Robert J. Gordon, "Historical Data, Appendix B." in Robert J. Gordon, The American Business Cycle: Continuity and Change (University of Chicago: Chicago, 1986), 781850 .

Basile, Peter, "The Cyclical Variation of Junk Bond Risk Premiums in a Historical Perspective: 1910-1955," (Rutgers University, Master's Thesis, 1989).

Battacharya, Sudipto and Anjan Thakor, "Contemporary Banking Theory," Journal of Financial Intermediation (October 1993), 2-50.

Bernanke, Ben S. (1983) "Non-Monetary Effects of the Financial Crisis in the Propogation of the Great Depression," American Economic Review 73 (June): 257-76.

Bernanke, Ben S., Laubach, Thomas, Mishkin, Frederic S. and Adam S. Posen (1999) Inflation Targeting: Lessons from the International Experience (Princeton: Princeton University Press).

Bernanke, Ben .S and Gertler Mark (1989). "Agency Costs, Collateral, and Business Fluctuations", American Economic Review, Vol. 79, pp. 14-31.

Brimmer, Andrew F. (1989) "Distinguished Lecture on Economics in Government: Central Banking and Systemic Risks in Capital Markets," Journal of Economic Perspectives 3 (Spring): 316.

Board of Governors of the Federal Reserve System, Banking and Monetary Statistics, 1914-1941 (1943).

Calomiris, C.W., Hubbard, R.G. (1990). "Firm Heterogeneity, Internal Finance, and Credit Rationing'", Economic Journal, 100, pp. 90-104.

Cecchetti, Stephen G., Hans Genburg, John Lipsky and Sushil Wadhwani, 2000. Asset Prices and Central Bank Policy, Geneva Reports on the World Economy (International Center for Monetary and Banking Studies and Centre for Economic Policy Research, London).

Economagic, www.economagic.com, stock indices.

Federal Reserve Bank of St. Louis, FRED. www.frstls.gov

Freelunch, www.economy,com, stock indices.

Friedman, Milton and Anna Jacobson Schwartz, A Monetary History of the United States, 18671960 (Princeton: Princeton University Press, 1963). 
Greenwald, B., Stiglitz, J.E. (1988) "Information, Finance Constraints, and Business Fluctuations", in Kahn, M., and Tsiang, S.C. (eds) Oxford University Press, Oxford.

Macaulay, Frederick R. (1938) The Movements of Interest Rates, Bond Yields and Stock Prices in the United States Since 1856 (New York: National Bureau of Economic Research).

Maisel, Sherman (1973) Managing the Dollar (New York: Norton).

Mishkin, Frederic S., "Asymmetric Information and Financial Crises: A Historical Perspective," in R. Glenn Hubbard, Financial Markets and Financial Crises (Chicago: Chicago University Press, 1991): 69-108.

Mishkin, Frederic S., "Symposium on the Monetary Transmission Mechanism," Journal of Economic Perspectives, 9, \#4 (Fall 1995): 3-10.

Mishkin, Frederic S., "The Causes and Propagation of Financial Instability: Lessons for Policymakers," Maintaining Financial Stability in a Global Economy (Federal Reserve Bank of Kansas City, Kansas City, MO., 1997): 55-96.

Mishkin, Frederic S. (2001) "Financial Policies and the Prevention of Financial Crises in Emerging Market Countries," NBER Working Paper No. 8397 forthcoming in Martin Feldstein, ed., Economic and Financial Crises in Emerging Market Countries (University of Chicago Press: Chicago).

Mishkin, Frederic S. and Klaus Schmidt-Hebbel (2002) "One Decade of Inflation Targeting in the World: What Do We Know and What Do We Need to Know?" in Norman Loayza and Raimundo Soto, eds. Inflation Targeting: Design, Performance, Challenges (Central Bank of Chile: Santiago 2002): 117-219.

Mussa, Michael, "Monetary Policy," in Martin Feldstein, American Economic Policy in the 1980s (Chicago: Chicago University Press, 1994).

National Bureau of Economic Research, Macro History Database.

Pierce, Phyllis, The Dow Jones Averages, 1885-1990 (Homewood, IL: Business One Irwin, 1991).

Rappoport, Peter and Eugene N. White, "Was There a Bubble in the 1929 Stock Market?" Journal of Economic History 53 (3) September 1993, 549-574.

Rappoport, Peter and Eugene N. White, "Was the Crash of 1929 Expected?" American Economic Review 84 (1) March 1994, 271-281.

Romer, David H. and Christina D. Romer, "Does Monetary Policy Matter" A Test in the Spirit of Friedman and Schwartz," NBER Macroeconomics Annual 1989 eds. Olivier Blanchard and 
Stanley Fisher, (Cambridge: MIT Press, 1989), pp. 121-170.

Romer, Christina, "The Great Crash and the Onset of the Great Depression," Quarterly Journal of Economics 105:3 (August 1990), pp. 597-624.

Sprague, O. M. W., History of Crises Under the National Banking System (U.S. Government Printing Office: Washington, D.C., 1910).

Svensson, L. (1997), "Inflation Forecast Targeting: Implementing and Monitoring Inflation Targets," European Economic Review, 41: 1111-1146.

Wall Street Journal "Economic Front: How Policy Makers Regrouped to Defend the Financial System," Tuesday, September 18, 2001, p. A1.

White, Eugene N., "The Stock Market Boom and Crash of 1929 Revisited," Journal of Economic Perspectives 4 (2), Spring 1990, 67-83.

White, Eugene N., The Comptroller and the Transformation of American Banking, 1960-1990 (Office of the Comptroller of the Currency: Washington, D.C., 1992).

White, Eugene N., "Banking and Finance in the Twentieth Century," in S. Engerman and R. Gallman, eds., The Cambridge Economic History of the United States Vol III. (Cambridge: Cambridge University Press, 2000), 743-802.

Wicker, Elmus, Banking Panics of the Gilded Age (Cambridge: Cambridge University Press, 2000). 
Figure 1

Crash of 1903

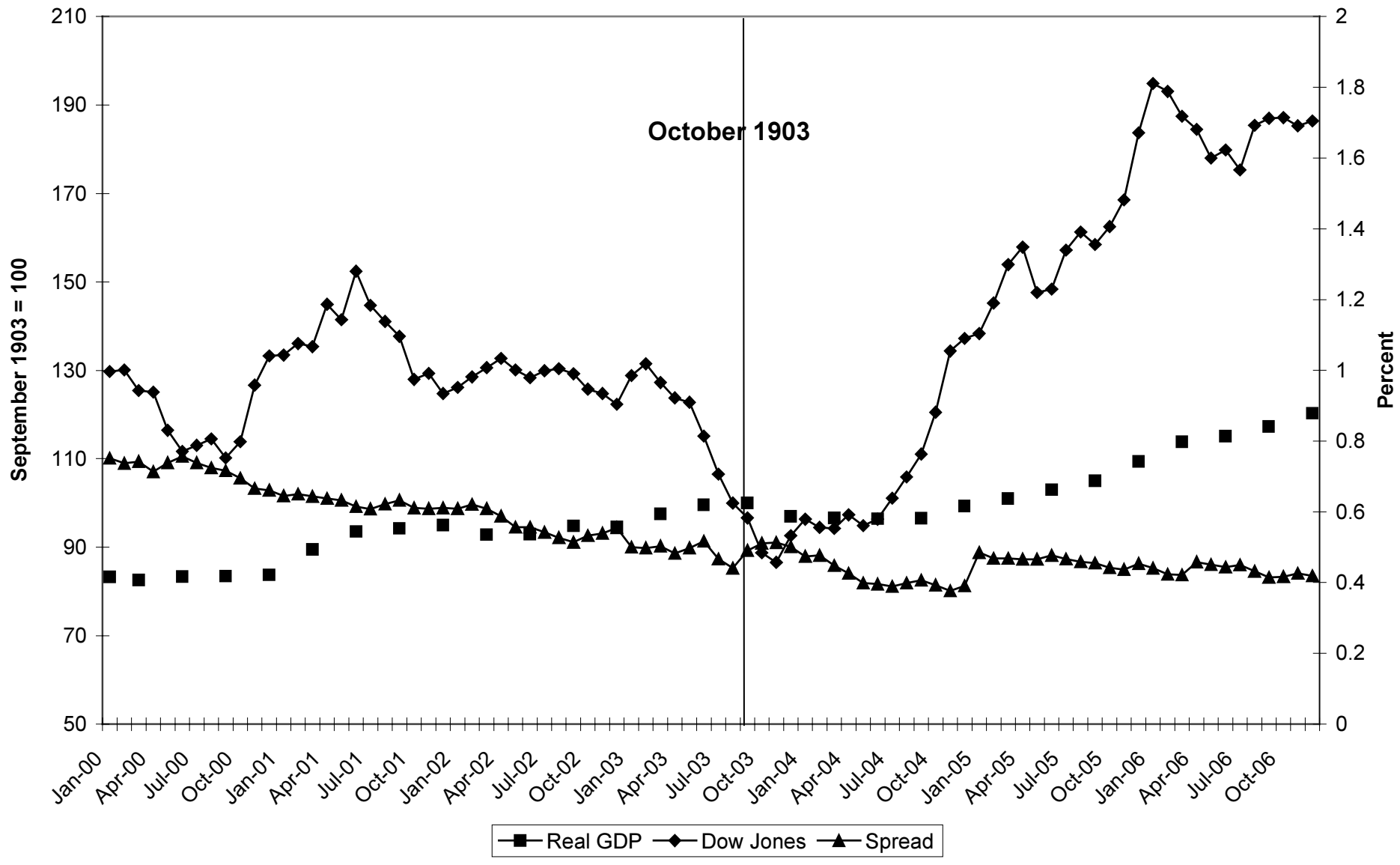


Figure 2

\section{Crash of 1907}

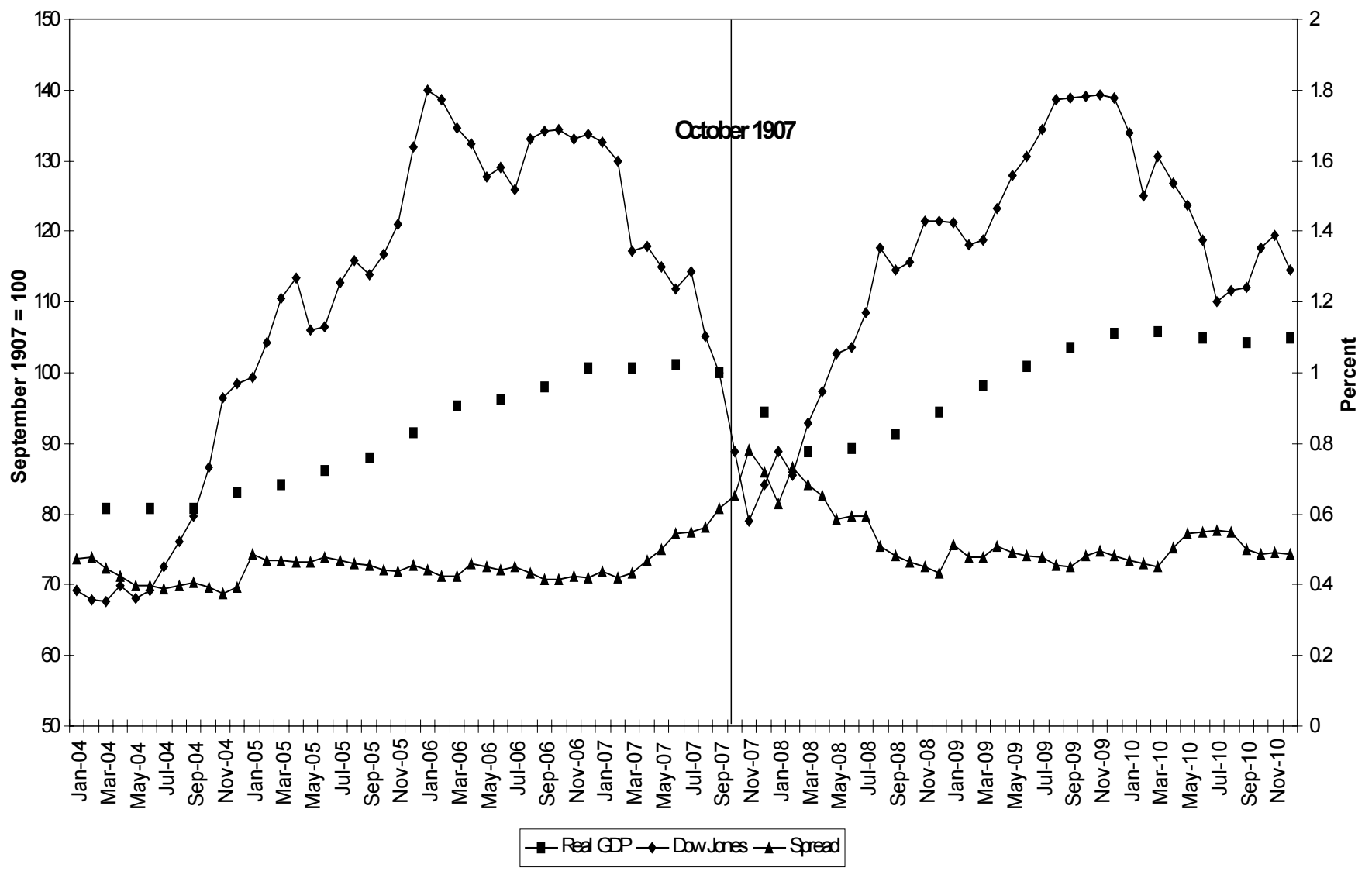


Figure 3

\section{Crashes of 1917 and 1920}

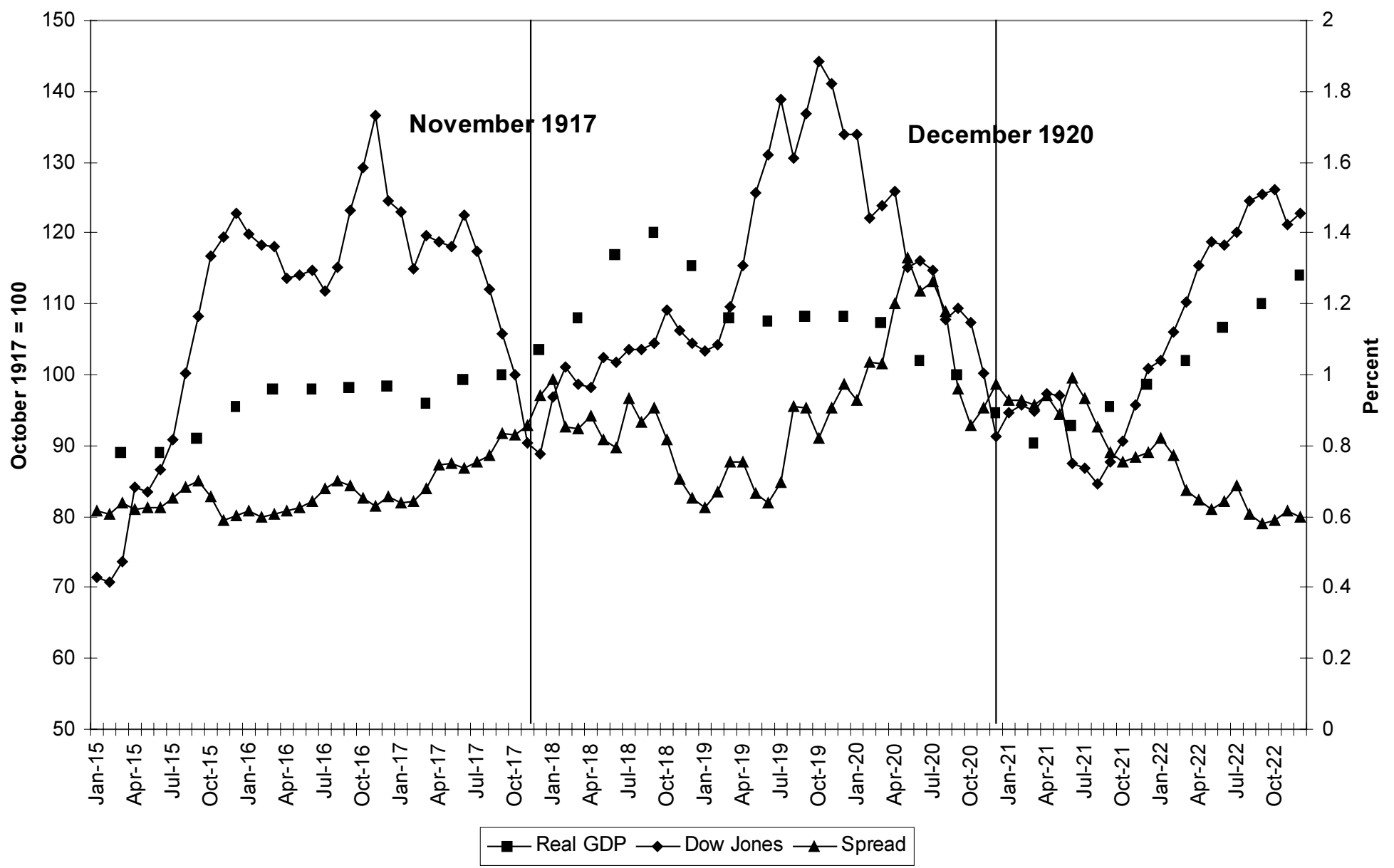


Figure 4

\section{Crash of 1929}

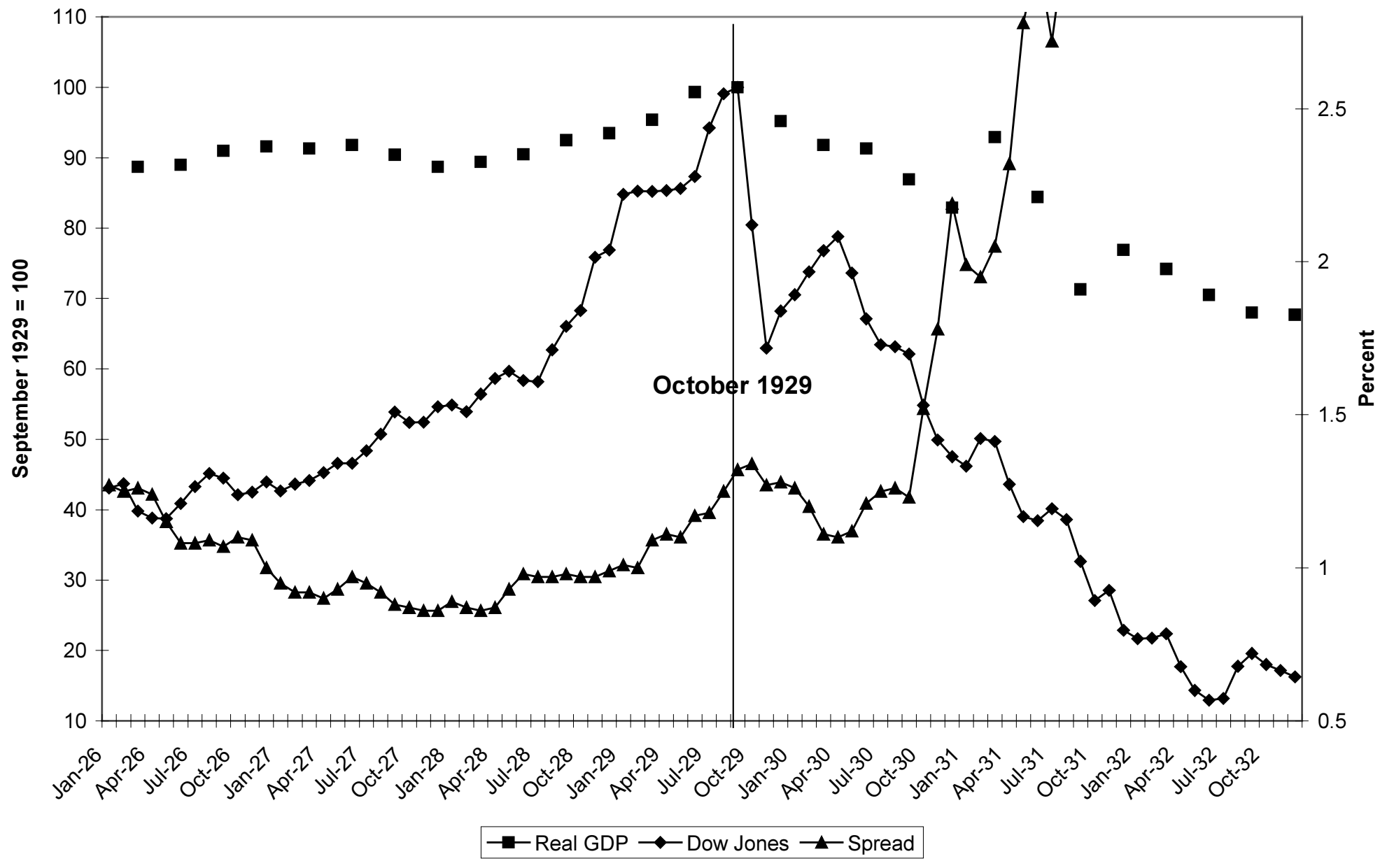


Figure 5

\section{Crashes of 1937}

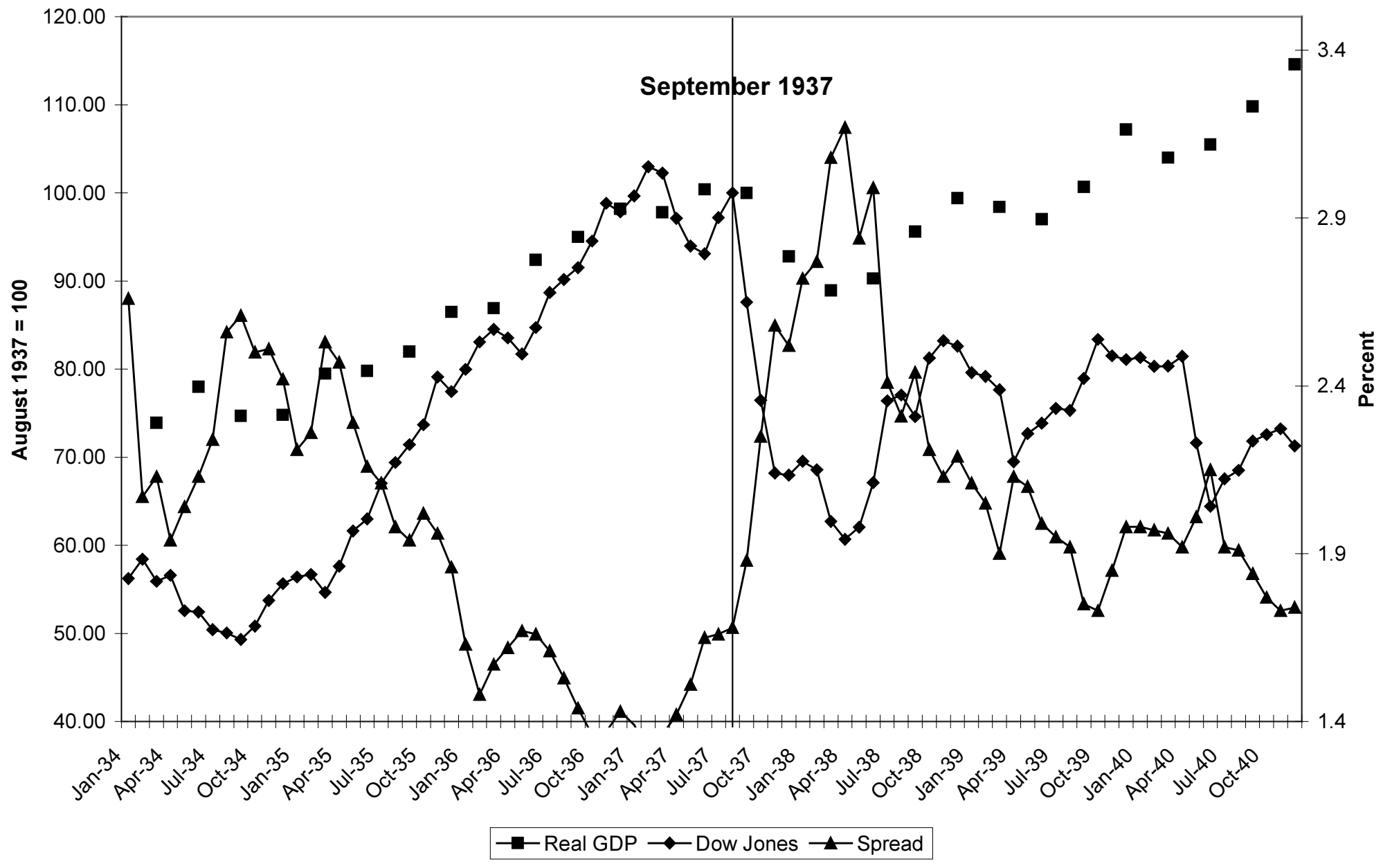


Figure 6

Crash of 1940

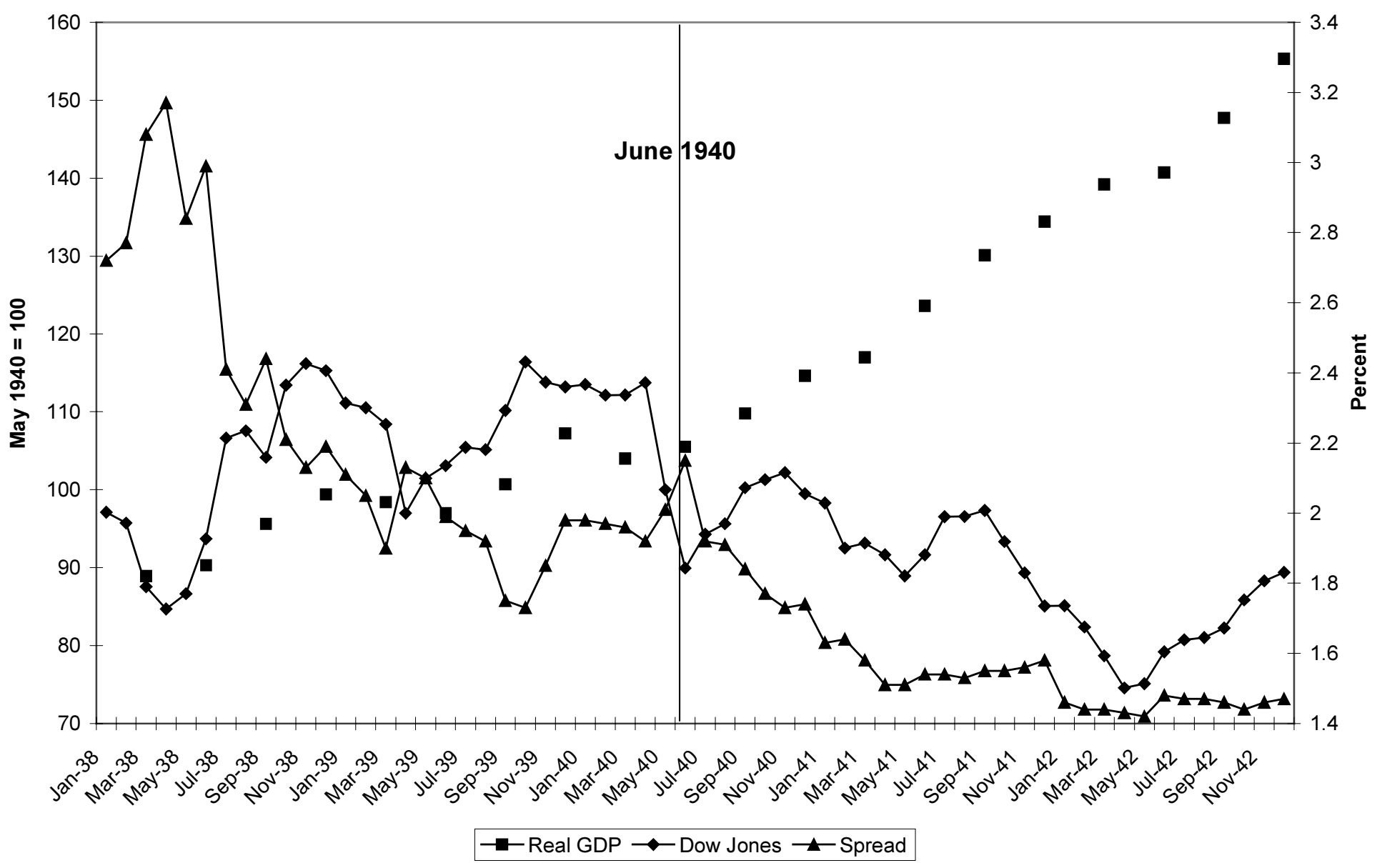


Figure 7

Crash of 1946

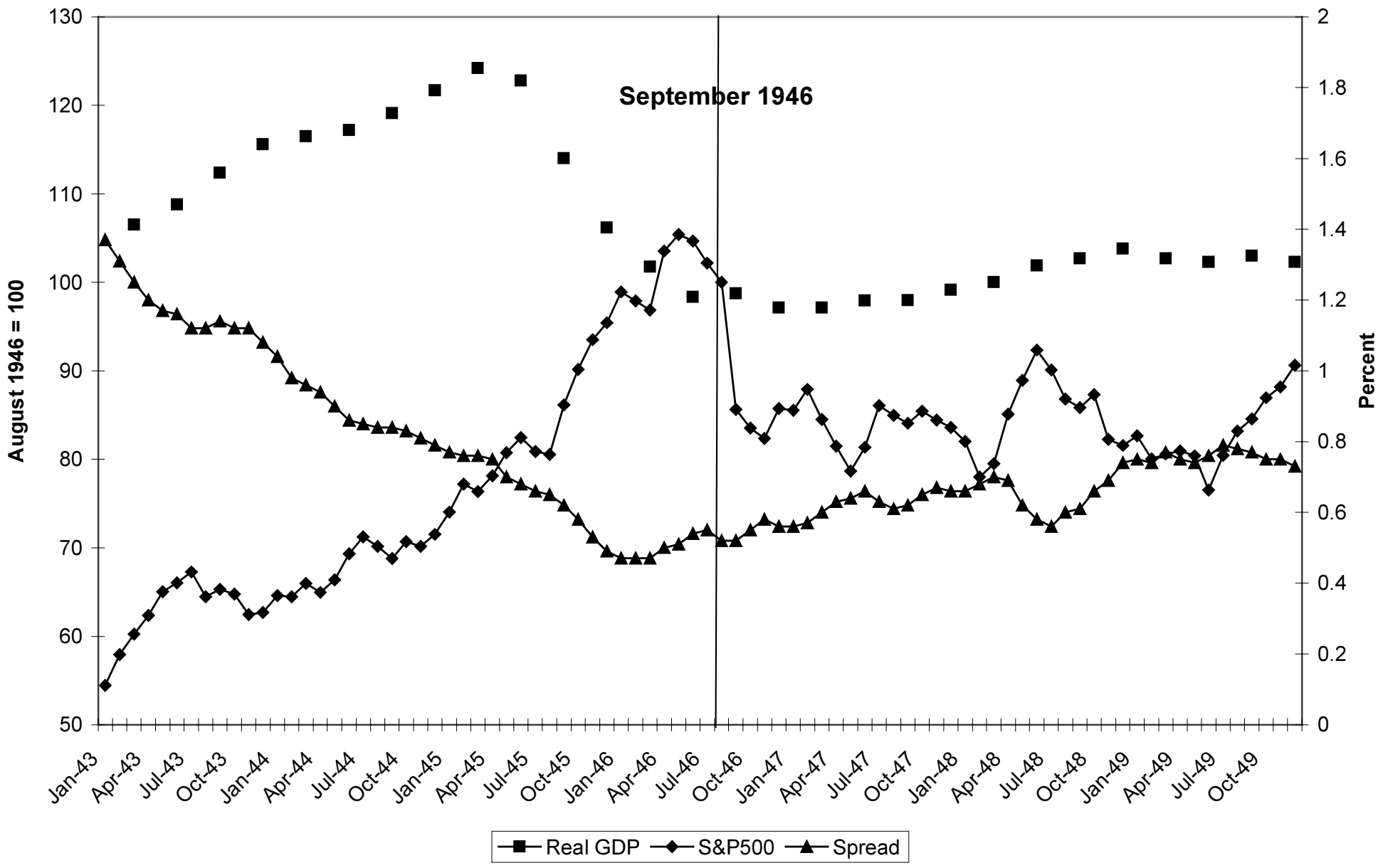


Figure 8

\section{Crash of 1962}

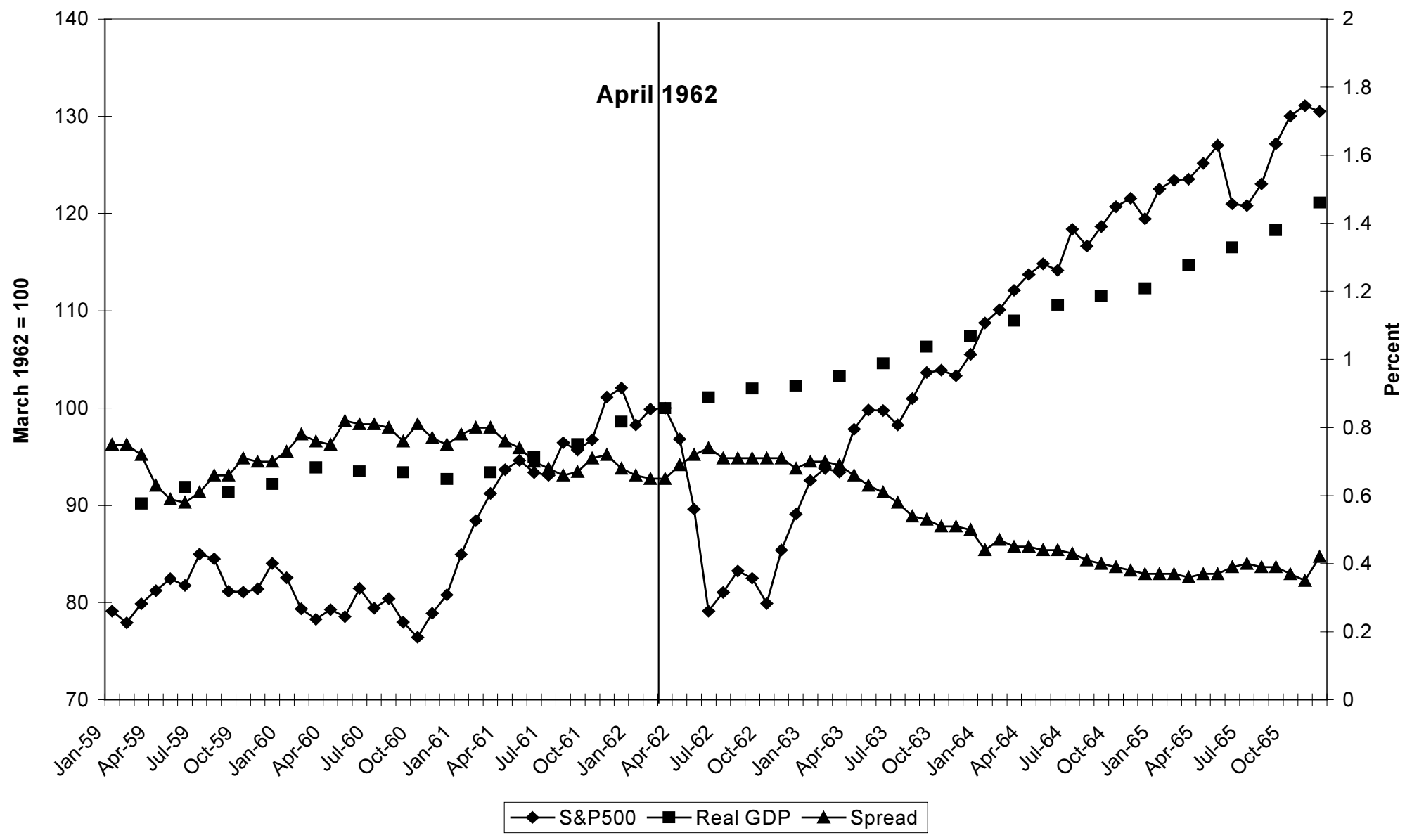


Figure 9

\section{Crash of 1970}

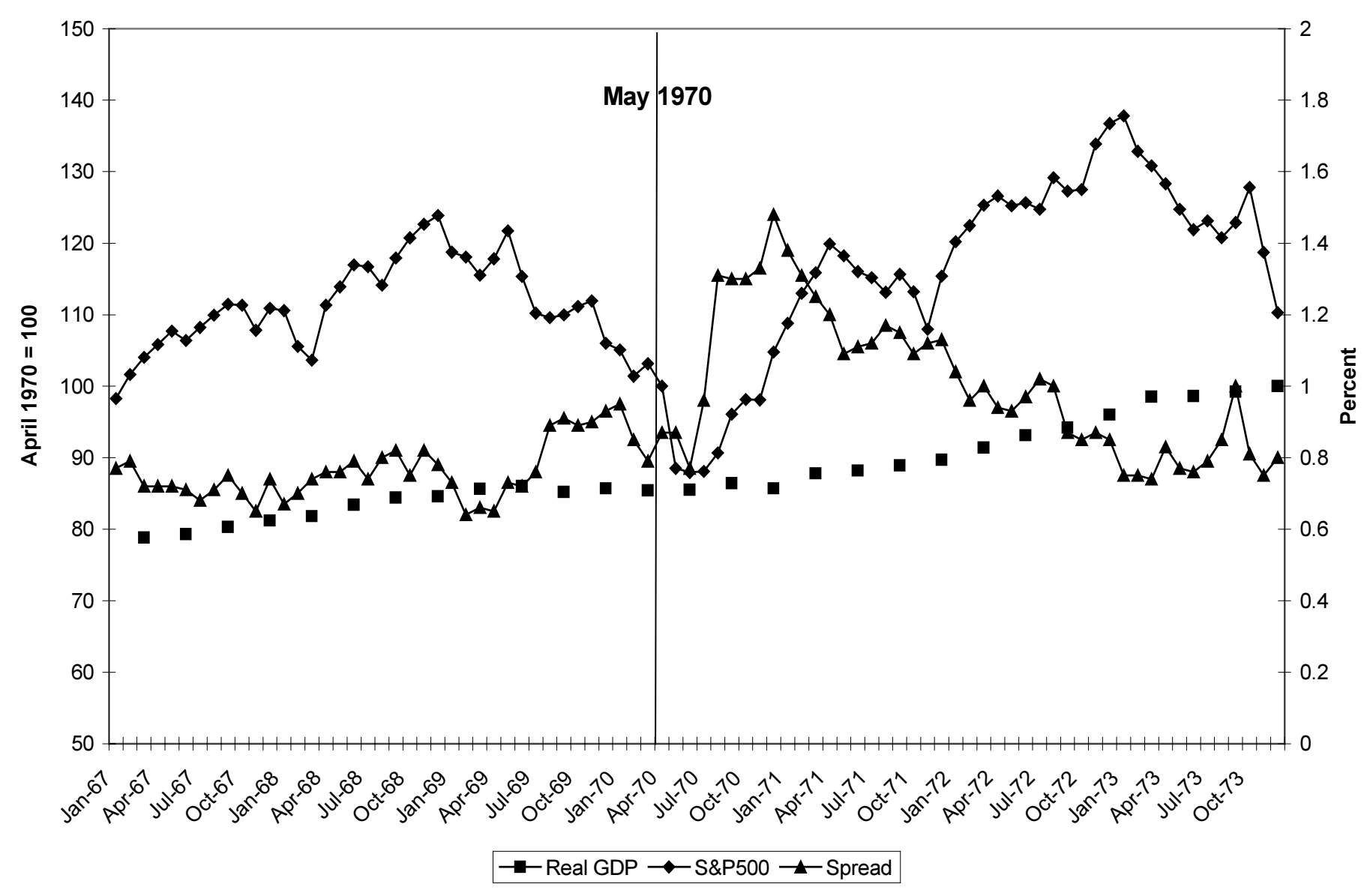


Figure 10

\section{Crash of 1973}

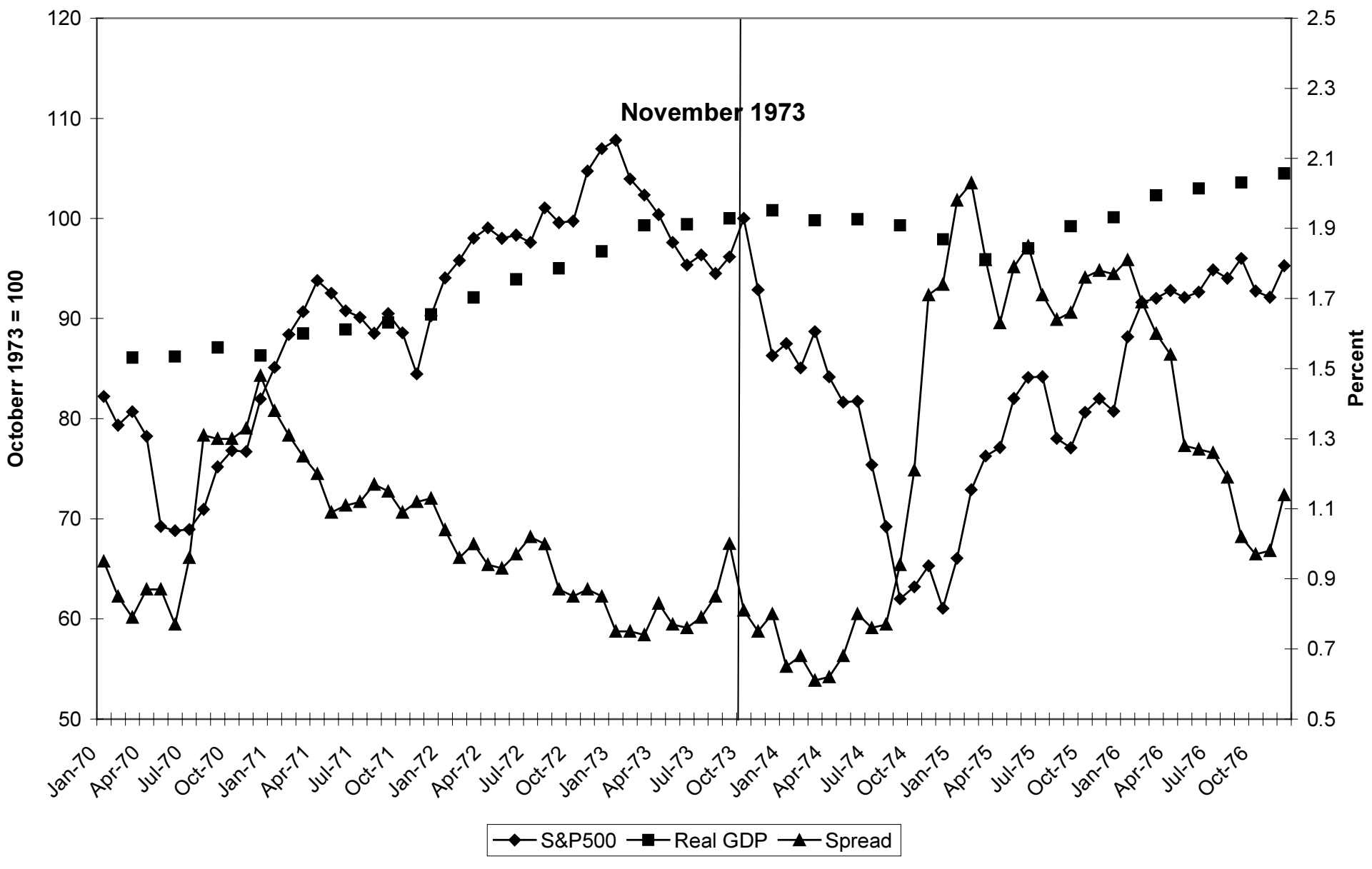


Figure 11

\section{Crash of 1987}

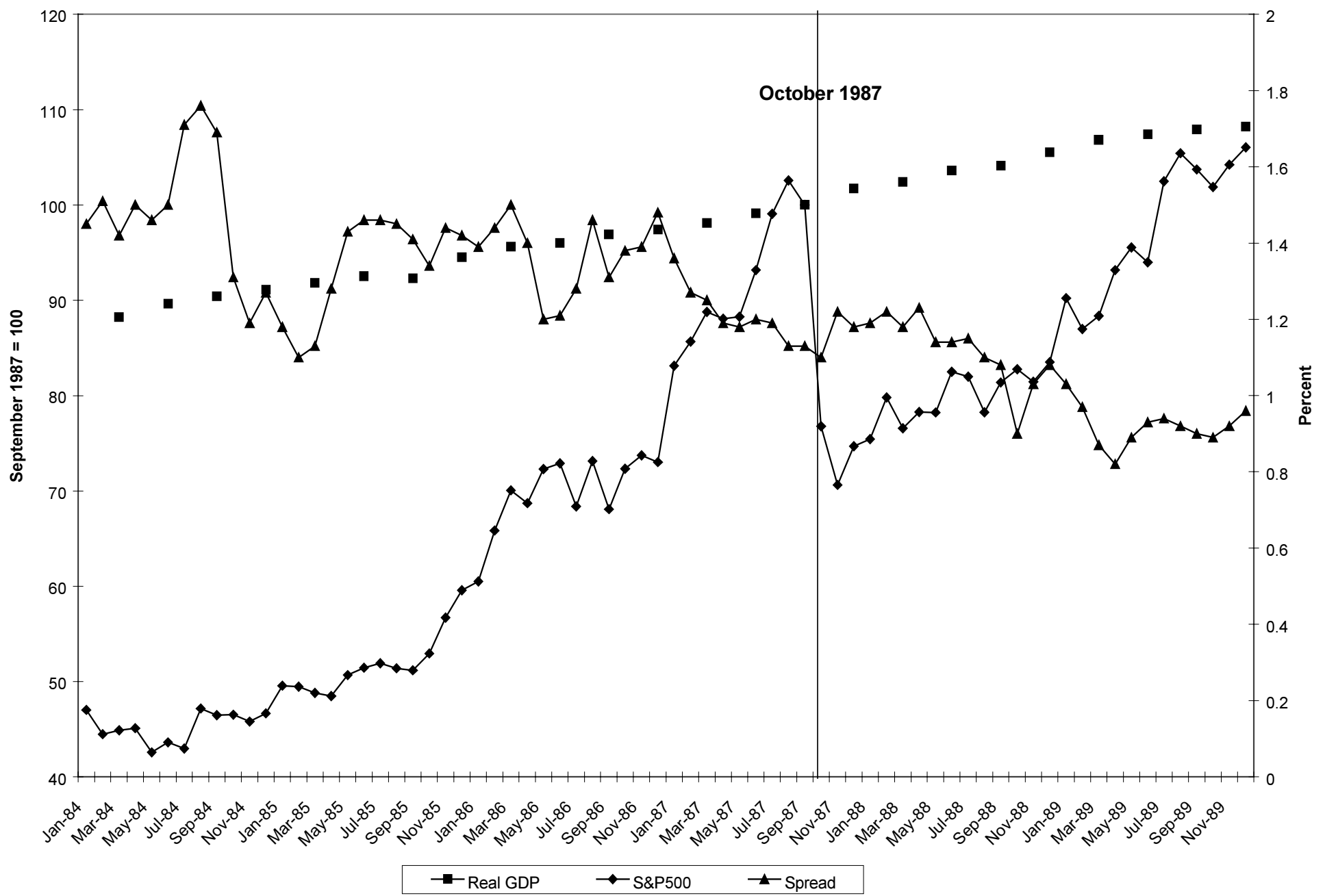


Figure 12

\section{Crash of 1990}

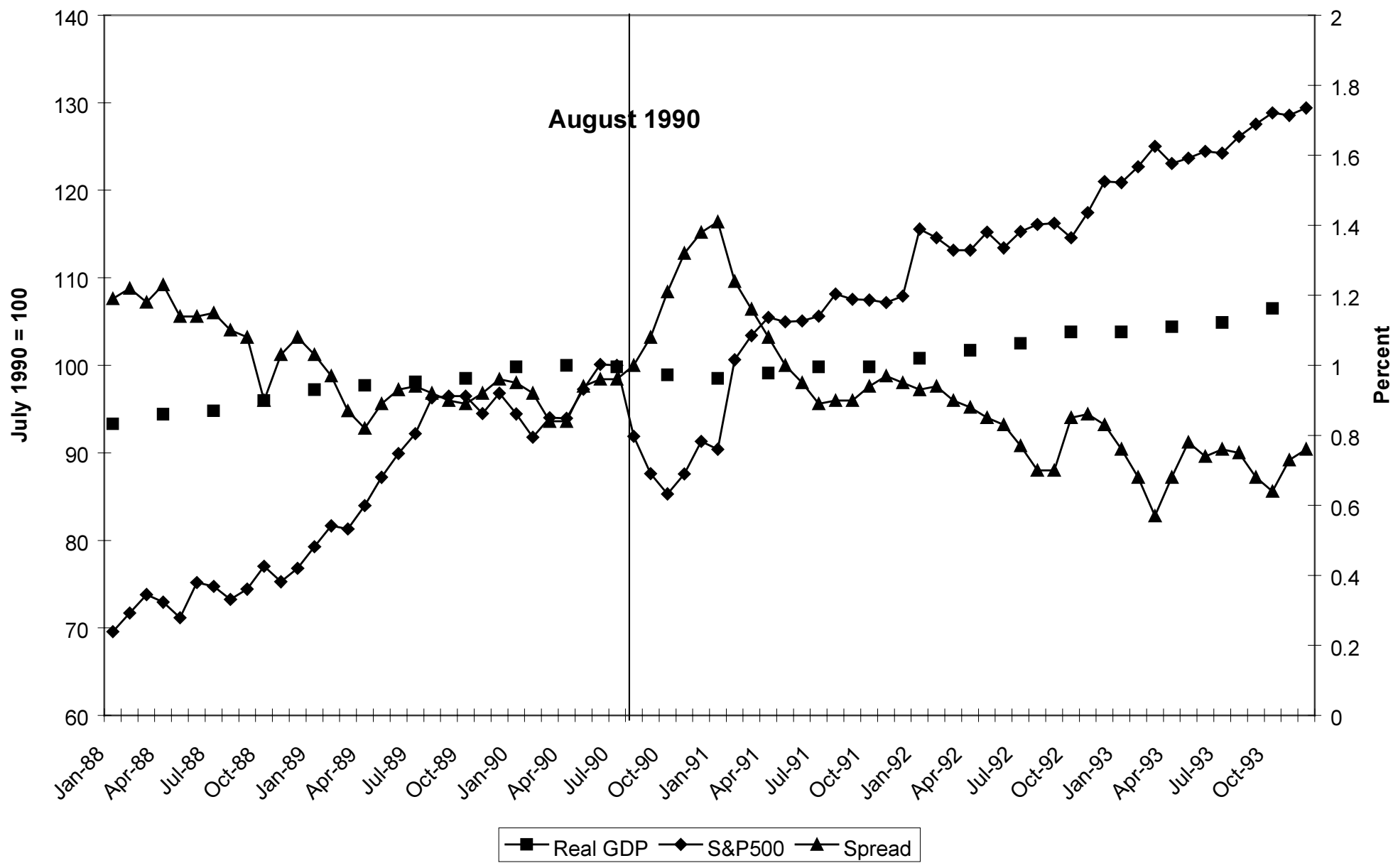


Figure 13

Crash of 2000

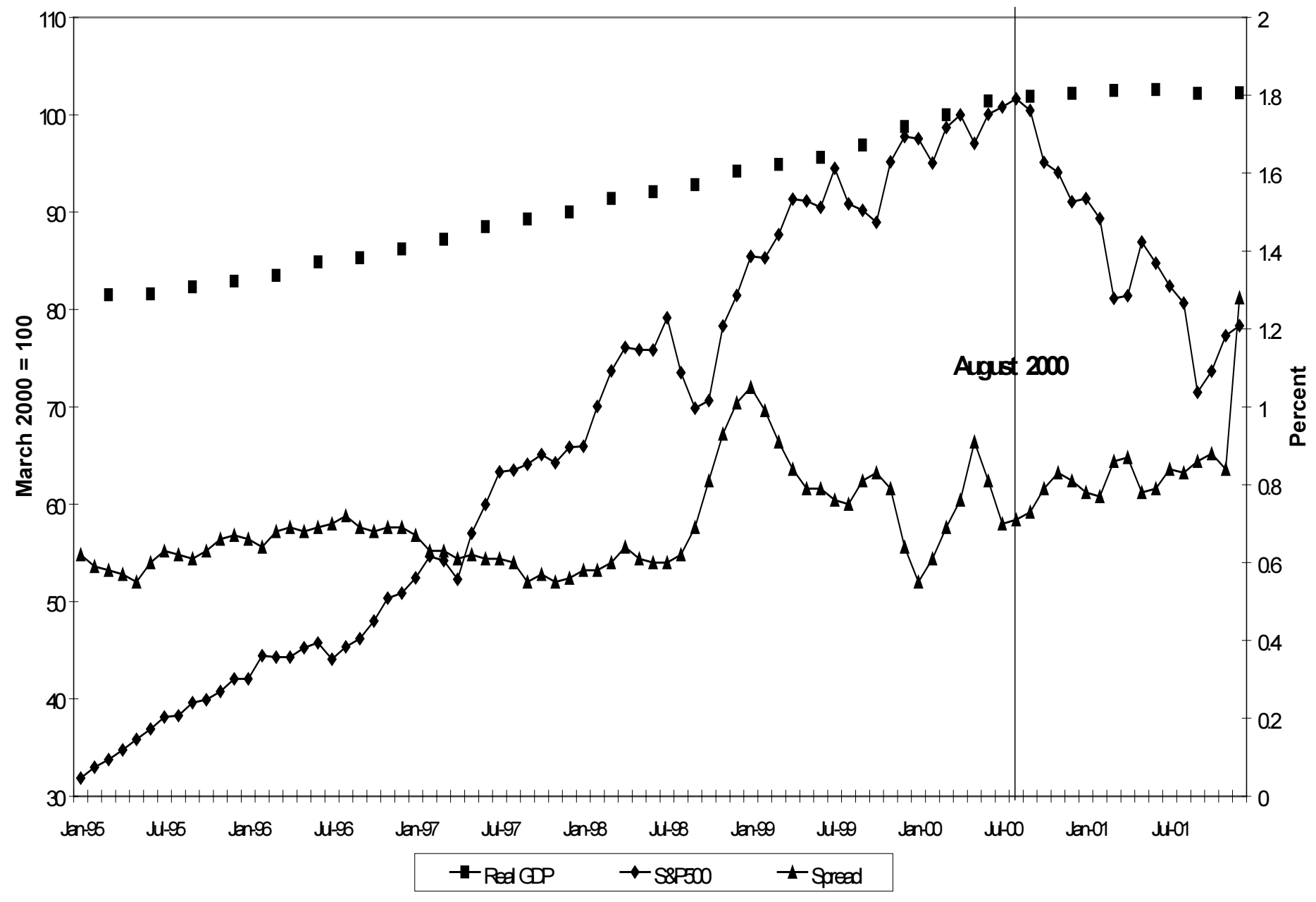

